\title{
Modeling and Regression Analysis of Semiochemical Dose- Response Curves of Insect Antennal Reception and Behavior
}

\author{
John A. Byers
}

Received: 8 January 2013 /Revised: 25 March 2013 / Accepted: 16 July 2013 /Published online: 30 July 2013

(C) Springer Science+Business Media New York (outside the USA) 2013

\begin{abstract}
Dose-response curves of the effects of semiochemicals on neurophysiology and behavior are reported in many articles in insect chemical ecology. Most curves are shown in figures representing points connected by straight lines, in which the $\mathrm{x}$-axis has order of magnitude increases in dosage vs. responses on the y-axis. The lack of regression curves indicates that the nature of the dose-response relationship is not well understood. Thus, a computer model was developed to simulate a flux of various numbers of pheromone molecules $\left(10^{3}\right.$ to $\left.5 \times 10^{6}\right)$ passing by $10^{4}$ receptors distributed among $10^{6}$ positions along an insect antenna. Each receptor was depolarized by at least one strike by a molecule, and subsequent strikes had no additional effect. The simulations showed that with an increase in pheromone release rate, the antennal response would increase in a convex fashion and not in a logarithmic relation as suggested previously. Non-linear regression showed that a family of kinetic formation functions fit the simulated data nearly perfectly $\left(R^{2}>0.999\right)$. This is reasonable because olfactory receptors have proteins that bind to the pheromone molecule and are expected to exhibit enzyme kinetics. Over 90 dose-response relationships reported in the literature of electroantennographic and behavioral bioassays in the laboratory and field were analyzed by the logarithmic and kinetic formation functions. This analysis showed that in $95 \%$ of the cases, the kinetic functions explained the relationships better than the logarithmic (mean of about $20 \%$ better). The kinetic curves become sigmoid when graphed on a log scale on the x-axis. Dose-catch relationships in the field
\end{abstract}

Electronic supplementary material The online version of this article (doi:10.1007/s10886-013-0328-6) contains supplementary material, which is available to authorized users.

J. A. Byers $(\bowtie)$

US Arid-Land Agricultural Research Center, USDA-ARS, 21881

North Cardon Lane, Maricopa, AZ 85138, USA

e-mail: john.byers@ars.usda.gov are similar to dose-EAR (effective attraction radius, in which a spherical radius indicates the trapping effect of a lure) and the circular $\mathrm{EAR}_{\mathrm{c}}$ in two dimensions used in mass trapping models. The use of kinetic formation functions for doseresponse curves of attractants, and kinetic decay curves for inhibitors, will allow more accurate predictions of insect catch in monitoring and control programs.

Keywords Computer simulation · Kinetic functions ·

Non-linear regression · Electrophysiology

Electroantennogram $\cdot$ EAG $\cdot$ Pheromone trap catch .

Olfactometer bioassay $\cdot$ Effective attraction radius

\section{Introduction}

It is apparent from many studies that dose-response curves of electroantennographic (EAG) voltages or neuronal spike frequencies, as well as bioassays in the laboratory, are plotted with a logarithmic scale on the x-axis (e.g., Al Abassi et al. 2000; Anderson et al. 1993; Byers 1983; Delorme and Payne 1990; Dickens et al. 1997; Dolzer et al. 2003; Gemeno et al. 2003; Hilbur et al. 2001; Moore 1981; Preiss and Priesner 1988; Schal et al. 1990; Teale et al. 1991). The plots of data points of increasing dosages usually are connected by straight lines, probably because the curvilinear relationships were poorly understood and complicated to plot. Researchers, as a general rule, know that biological response increases slowly as a function of large increases in semiochemical dose. Thus, they have usually used order of magnitude steps in the release or dosage of semiochemicals (e.g., Byers 1983, 1988; Byers et al. 1979, 1988; Chuman et al. 1987; Grant and Lanier 1982; Jewett et al. 1996; Moore 1981; Schlyter et al. 1987; Teale et al. 1991; Tilden and Bedard 1985). In regard to mass trapping, Byers (2007) suggested that a linear increase in pheromone release rate should result in a logarithmic increase in catch (using data from Byers 1988, and Byers et al. 1988). 
In practical terms, this means that exponentially more pheromone needs to be released for a linear increase in catch (Byers 2007). For example, if $Y$ is response and $X$ is pheromone release rate, then $\mathrm{Y}=\mathrm{a}+\mathrm{b} \ln (\mathrm{X})$, and response increases as the $\log$ of release rate. Solving for the pheromone release rate would give $\mathrm{X}=\exp [(\mathrm{Y}-\mathrm{a}) / \mathrm{b}]$, showing that an exponential increase in release rate is needed to give a linear increase in response.

The question then arises; does a logarithmic relationship describe dose-response curves in the laboratory and field better than other functions? In the course of analyzing the literature for dose-response curves to see how well logarithmic and other relationships fit the data, it became apparent that various kinetic formation functions fit the data better. This is reasonable, because enzymes function intimately in semiochemical reception by the antenna and in neuronal conductance of signals to the brain (Leal 2005; Rützler and Zwiebel 2005; Sachse and Krieger 2011). However, to my knowledge, there are no simulation models that describe the basic mechanism of the semiochemical dose and antennal response relationship that is crucial for behavioral activity, orientation, and catch in the field. It is fair to say that such models, as well as non-linear regression analysis of dose-response "curves", have been little explored in chemical ecology.

Dose-response curves are related to the effective attraction radius (EAR), which is a spherical volume in the field that describes the attractive effect of a semiochemical lure and trap. The EAR is defined by the silhouette area of the blank trap, and the ratio of catch between the attractive semiochemical traps and the blank traps (Byers 2009, 2012a, b; Byers et al. 1989;). For example, if a blank sticky sphere of $0.1 \mathrm{~m}^{2}$ silhouette area catches one insect per day, and if a pheromone trap catches 50 insects per day, then, in effect, the pheromone trap's silhouette area (A) is 50 times larger $\left(A=5 \mathrm{~m}^{2}\right)$. Thus, the radius of the pheromone sphere or silhouette is $(\mathrm{A} / \pi)^{0.5}=1.26 \mathrm{~m}$. Changes in the density of flying insects do not alter the EAR, since this is based on a ratio of catch on active and blank traps. The EAR has been used to compare the strengths of lures, either among species, blends, or dosages, or any combination thereof. The EAR can be used in detection and monitoring (Byers 2012a, b) or to predict population reduction due to mass trapping with different initial values for densities of insects and traps, and trapping duration (Byers 2007, 2012b). Because modeling in two dimensions is easier and faster than in three dimensions, the EAR can be transformed to a circular $\mathrm{EAR}_{\mathrm{c}}$ in two dimensions for use in mass trapping models (Byers 2009). The transformation, however, requires estimation of the standard deviation of the vertical flight distribution of the insect (Byers 2011). As EAR and EAR $\mathrm{C}_{\mathrm{c}}$ both depend on catch, how do they change according to a dose-response relationship in the field?
The first objective of this study was to develop a simple model of antennal reception of semiochemicals and determine the type of relationship between dosage of semiochemical and spike frequency, or EAG voltage, of the antenna. The second objective was to use linear and non-linear regression to test both the logarithmic and kinetic formation functions (enzyme kinetics) for fit to the generated data of the simulation model. The third objective was to analyze the data similarly from many studies in the literature for EAG, laboratory bioassay, and field catches with regard to dosage or release rate of semiochemical. A better understanding of dose-response curves in chemical ecology should result from these analyses and modeling. In addition, methods for fitting dose-response curves with kinetic functions will allow more accurate estimation of the trap lure's EAR and $\mathrm{EAR}_{\mathrm{c}}$ for predicting insect catches in monitoring and mass trapping programs.

\section{Methods and Materials}

Computer Modeling of Semiochemical Release Rate and EAG Responses To test, theoretically, the fundamental relationship of antennal response to a linear increase in pheromone release rate, a simple computer model is proposed. The simulation assumes there is a flux of pheromone molecules passing the antennae and some of the molecules may strike receptors (Fig. 1). Any molecule striking a receptor causes a contributing signal (depolarization), and subsequent strikes by other molecules on this depolarized receptor have no effect (i.e., a competitive effect). The model was programmed in Java 6 language (Oracle, Redwood Shores, CA, USA) to have 23 different numbers of molecules ( $n$ ranging from $10^{3}$ to $5 \times 10^{6}$ ) strike an antenna with $10^{4}$ receptors distributed evenly among

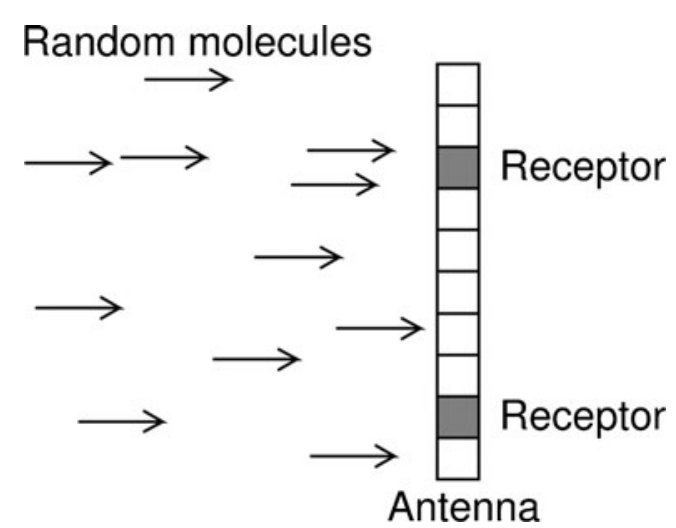

Fig. 1 In theory, a flux of pheromone molecules ranging from $10^{3}$ to $5 \times 10^{6}$ (represented by arrows) may randomly strike non-sensory positions (represented as white cells) or receptors (darker cells) on an insect antenna that is simulated as a memory array of $10^{6}$ positions, of which $10^{4}$ are receptors. The simulation determines the number of receptors that are hit by a molecule at least once (some receptors are missed while others are struck multiple times). In the diagram, there would be two hits of the receptors from 11 pheromone molecules 


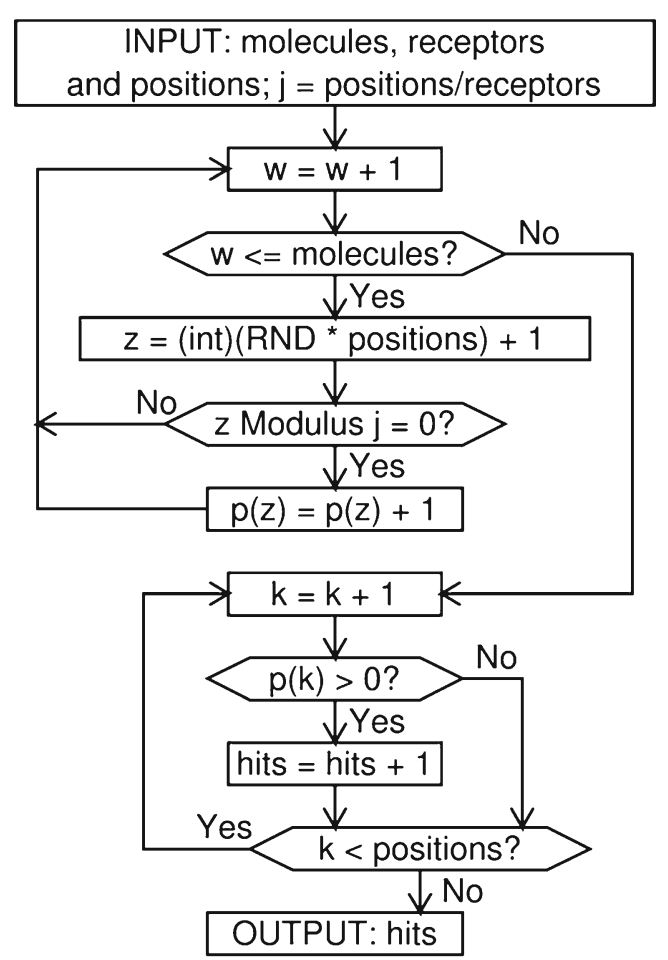

Fig. 2 Flow diagram of a computer simulation of a flux of pheromone molecules randomly impacting a hypothetical antenna with a large number of positions $\left(10^{6}\right)$ upon which a much smaller number of receptors $\left(10^{4}\right)$ are placed. The hits are the number of receptors that are stimulated by at least one pheromone molecule to produce a spike (these would summate resulting in an EAG or spike frequency)

$10^{6}$ possible positions (i.e., every 100 th position), acting as described above (Fig. 2). These numbers are not necessarily realistic but should describe the essential dynamics. Thus, a random whole number, $\mathrm{z}$, from 1 to $10^{6}$, was chosen $n$ times, where each $\mathrm{z}$ represents one of the $10^{6}$ positions on the antenna. As receptors were evenly distributed in $1 / 100$ of the possible positions, if a random $\mathrm{z}$ is evenly divisible by 100 , then this corresponds to a hit of a receptor at position $\mathrm{z}[$ i.e., $\mathrm{z}$ modulus $\left(10^{6} / 10^{4}\right)$ equals 0 ] and the memory array cell for this position is incremented. After each flux of molecules, the memory array was searched for cells with counts of one or more to obtain a number of receptor hits or receptors depolarized (Fig. 2). The simulations were repeated eight times for each $n$, and the resulting mean hits and $95 \%$ confidence intervals $(\mathrm{CI})$ recorded.

Non-linear Regression Functions Fitting Dose-response Curves of Simulated and Experimental Data Sixty six simple functions and 22 kinetic formation functions were fit by linear and non-linear regression to the 23 data points of $n$ molecules vs. hits using TableCurve 2D version 5.01 (Systat Software Inc., Chicago, IL, USA). The simple functions included the common logarithmic function $[\mathrm{Y}=\mathrm{a}+\mathrm{b} \ln (\mathrm{X})]$. One of $12 \mathrm{ki}-$ netic functions (Results) that fit the data of the model nearly exactly $\left(R^{2}>0.999\right)$ was $\mathrm{Y}=\mathrm{a}+\mathrm{b}(1-\exp (-\mathrm{cX}))$, and the intercept (a) could be randomly assigned negative values to obtain many different receptor sensitivity curves by plotting only positive $\mathrm{Y}$ values. The sum of these curves can represent the EAG signal that is a sigmoid curve or logistic form that is sometimes seen in the literature of dose-response curves (Van Giessen et al. 1994; Sans et al. 1997). To demonstrate this effect, the QuickBASIC 4.5 language (Microsoft Corp., Redmond, WA, USA) was used to generate 50 such curves by setting $a=-4000$ (RND), where RND is a uniform random number between 0 and $1, b=3999(R N D)+6000$, and $\mathrm{c}=5 \times 10^{-7}(\mathrm{RND})+5 \times 10^{-7}$. The $\mathrm{Y}$ values of the 50 curves were summed at 100 places along the $\mathrm{X}$-axis (every $5 \times 10^{4}$ ) to obtain a composite curve that was fit by the same functions above.

Dose-response curves for EAG, behavioral activities in the laboratory, or insect catch in the field were obtained from the literature (my knowledge and aided by keywords "dose response") and fit to the 18 best-fitting functions found for the simulated data. In addition, these data were fit by a logarithmic function because the relationship between pheromone release rate and catch in the field is often described in this manner (Byers 2012b). Because Van Giessen et al. (1994) suggested a logistic function would fit dose-response curves, the EAG data sets were subjected to regression with a logistic function, $\mathrm{Y}=\mathrm{a} /\left(1+\mathrm{X} / \mathrm{b}^{\mathrm{c}}\right)$. In contrast to attractants, inhibitors, such as verbenone, reduce orientation responses (in this example, by the bark beetle Dendroctonus brevicomis to its aggregation pheromone; Tilden and Bedard 1988). These inhibitor dose-response data were fit by 14 kinetic decay functions. For all data sets extracted from the literature, the adjusted $R^{2}\left(\bar{R}^{2}\right)$ was reported instead of $R^{2}$. This is because several regression models were compared that had from $2-5$ terms (Table 1) and the data sets had relatively few points $(N \leq 6)$. Dose-response data were obtained from articles in PDF format (Adobe Systems, Inc., San Jose, CA) by screencapturing the figures and pasting the images into a paint program (Paint Shop Pro 5.0, Jasc Software, Corel Corp., Ottawa, Canada). The mouse cursor then was used to obtain $y$ coordinates of image pixels representing various data points that were converted to y-data values $\left(D_{y}\right)$ by the following formula:

$D_{y}=\frac{\left(y_{0}-y_{d}\right) \cdot N_{y}}{\left(y_{0}-y_{N}\right)}$

where $y_{0}=$ pixel value at y-axis zero, $y_{d}=$ pixel value at y-value of interest, $N_{y}=$ number representing highest $\mathrm{Y}$ in graph, and $y_{N}=$ pixel value at $N_{y}$. For example, if $y_{0}=694, y_{d}=442$, $y_{N}=244$, and $N_{y}=500$, then $D_{y}=280$ insects/trap/day. Responses (EAG or behavioral) that were not considered higher than the control (no semiochemical), or those that were zero, 
Table 1 Kinetic formation functions fitted to simulated and experimental data of semiochemical dose and insect response

\begin{tabular}{|c|c|c|}
\hline Function & Regression function & Description \\
\hline $\mathrm{A}(8100)^{\mathrm{a}}$ & $\mathrm{Y}=\mathrm{a}(1-\exp (-\mathrm{bX}))$ & 1 st order, through origin \\
\hline B (8101) & $\mathrm{Y}=\mathrm{a}+\mathrm{b}(1-\exp (-\mathrm{cX}))$ & 1 st order, intercept form \\
\hline $\mathrm{C}(8124)$ & $\mathrm{Y}=\mathrm{a}(1-\mathrm{b} /((\mathrm{b}+\mathrm{ac}) \exp (\mathrm{bX})-\mathrm{ac}))$ & 1 st and second order, origin \\
\hline $\mathrm{D}(8125)$ & $\mathrm{Y}=\mathrm{a}+\mathrm{b}(1-\mathrm{c} /((\mathrm{c}+\mathrm{bd}) \exp (\mathrm{cX})-\mathrm{bd}))$ & 1st and second order, intercept \\
\hline $\mathrm{E}(8120)$ & $\mathrm{Y}=\mathrm{a}-\left(\mathrm{a}^{(1-\mathrm{c})}+\mathrm{bX}(\mathrm{c}-1)\right)^{(1 /(1-\mathrm{c}))}$ & Variable order, through origin \\
\hline $\mathrm{F}(8121)$ & $\mathrm{Y}=\mathrm{a}+\mathrm{b}-\left(\mathrm{b}^{(1-\mathrm{d})}+\mathrm{cX}(\mathrm{d}-1)\right)^{(1 /(1-\mathrm{d}))}$ & Variable order, intercept form \\
\hline $\mathrm{G}(8150)$ & $\mathrm{Y}=\mathrm{a}(1-\exp (-\mathrm{bX}))+\mathrm{c}(1-1 /(1+\mathrm{cdX}))$ & 2 nd order independent, origin \\
\hline $\mathrm{H}(8151)$ & $\mathrm{Y}=\mathrm{a}+\mathrm{b}(1-\exp (-\mathrm{cX}))+\mathrm{d}(1-1 /(1+\mathrm{deX}))$ & 2nd order independent, intercept \\
\hline I (8136) & $\mathrm{Y}=\mathrm{a}(1+(\mathrm{bexp}(-\mathrm{cX})-\operatorname{cexp}(-\mathrm{bX})) /(\mathrm{c}-\mathrm{b}))$ & 1st order sequential, origin \\
\hline $\mathrm{J}(8137)$ & $\mathrm{Y}=\mathrm{a}+\mathrm{b}(1+(\operatorname{cexp}(-\mathrm{dX})-\operatorname{dexp}(-\mathrm{cX})) /(\mathrm{d}-\mathrm{c}))$ & 1st order sequential, intercept \\
\hline K (8146) & $Y=a(1-\exp (-b X))+c(1-\exp (-d X))$ & Two 1 st order independent, origin \\
\hline $\mathrm{L}(8147)$ & $\mathrm{Y}=\mathrm{a}+\mathrm{b}(1-\exp (-\mathrm{cX}))+\mathrm{d}(1-\exp (-\mathrm{eX}))$ & Two 1st order independent, intercept \\
\hline M (8104) & $\mathrm{Y}=\mathrm{a}(1-1 /(1+\mathrm{abX}))$ & 2 nd order, through origin \\
\hline N (8105) & $\mathrm{Y}=\mathrm{a}+\mathrm{b}(1-1 /(1+\mathrm{bcX}))$ & 2nd order, intercept form \\
\hline $\mathrm{O}(8108)$ & $\mathrm{Y}=\mathrm{aX} /(\mathrm{b}+\mathrm{X})$ & 2nd order hyperbolic, origin \\
\hline P (8109) & $\mathrm{Y}=\mathrm{a}+\mathrm{bX} /(\mathrm{c}+\mathrm{X})$ & 2 nd order hyperbolic, intercept \\
\hline Q (8112) & $\mathrm{Y}=\mathrm{a}\left(1-1 /\left(1+2 \mathrm{a}^{2} \mathrm{bX}\right)^{0.5}\right)$ & 3 rd order, through origin \\
\hline R (8113) & $\mathrm{Y}=-\mathrm{a}+\mathrm{b}\left(1-1 /\left(1+2 \mathrm{~b}^{2} \mathrm{cX}\right)^{0.5}\right)$ & 3 rd order, intercept form \\
\hline
\end{tabular}

${ }^{\mathrm{a}}$ Numbers in parentheses indicate function numbers used by TableCurve 2D

${ }^{a}$ Numbers in parentheses indicate
function numbers used by
TableCurve $2 \mathrm{D}$

were not used in regressions, because low dosages with no effect on response on a log scale would bias the analysis.

Plotting Kinetic Formation Functions on Logarithmic X-axis Scales Dose-response data are usually represented on a $\log$ scale for dosage, but plotting is simplified by using order of magnitude dosages that are evenly spaced along the $\mathrm{x}$-axis. The simulation model generated dose-response data that were plotted on a linear scale and fit by the logarithmic and kinetic functions. Thus, it is of interest to determine the shape of one of the kinetic functions $[\mathrm{Y}=\mathrm{a}(1-\exp (-\mathrm{bX}))]$ that fitted the simulated data well and compare this to a logarithmic function on a logarithmic scale. Plotting a continuous dosage $(\mathrm{X})$ on a $\log$-scale was accomplished with the following formula:

$X=\frac{\log (\alpha)-\log (\text { low })}{\log (\text { high })-\log (\text { low })}$

where low $=$ the lowest $X$ value, high=the highest $X$ value, and $\alpha$ are the $\mathrm{X}$ values to plot between low and high. The $\mathrm{Y}$ values (responses) were plotted on a linear scale.

Comparison of Dose-response Curves and EAR and EAR $R_{c}$ in the Field A dose-response curve, based on the kinetic function $\mathrm{C}_{\mathrm{a}}=\mathrm{a}+\mathrm{b}(1-\exp (-\mathrm{cX}))$, where $\mathrm{C}_{\mathrm{a}}=$ insect catch, can be converted to the spherical EAR, assuming a specific silhouette area (S) for a sticky trap and a catch of 1 on the blank sticky trap $\left(\mathrm{C}_{\mathrm{b}}\right)$, according to the formula: $\mathrm{EAR}=\left[\left(\mathrm{C}_{\mathrm{a}} \mathrm{S}\right) /\left(\pi \mathrm{C}_{\mathrm{b}}\right)\right]^{0.5}$ (Byers et al. 1989). The $\mathrm{EAR}_{\mathrm{c}}$ (circular or two-dimensional EAR) is calculated from the EAR and the standard deviation, SD, of the vertical flight distribution of the insect according to: $\mathrm{EAR}_{\mathrm{c}}=$ $\pi \mathrm{EAR}^{2} /\left[2 \mathrm{SD}(2 \pi)^{0.5}\right]$ (Byers 2009,2011$)$. To demonstrate the respective relationships between dose and trap catch, EAR and $\mathrm{EAR}_{\mathrm{c}}$, the catch of Ips typographus in response to cis-verbenol aggregation pheromone was used (Schlyter et al. 1987). An estimate of the beetle's vertical flight $\mathrm{SD}$, required for the calculation of $\mathrm{EAR}_{\mathrm{c}}$, was obtained from Byers et al. (1989).

\section{Results}

Computer Modeling of Semiochemical Release Rate and EAG Responses A flux of semiochemical molecules passing randomly by an antennal surface with many positions upon which a limited number of receptors are distributed (Fig. 1) was simulated in a computer program (Fig. 2). The simulations generated the variable, hits, which is the number of receptors (e.g., 10 $0^{4}$ ) distributed among $10^{6}$ positions on the antenna (every $\mathrm{j}^{\text {th }}$ position, where $\mathrm{j}=$ positions $/$ receptors $=100$ ) that are struck at least once by a molecule in a flux of many (e.g., 2,000,000) passing by at random. In this case, the mean number of depolarized receptors (hits) was 8,650 $\pm 19( \pm 95 \%$ $\mathrm{CL}, N=8$ ), or $86.5 \%$ of the receptors were stimulated. The simulations generated a relationship between number of molecules in a flux and the resulting hits (or number of receptors stimulated); this relationship was analyzed in the next section.

Non-linear Regression Functions Fitting Dose-response Curves of Simulated and Experimental Data Many of the kinetic formation functions fit the simulated data nearly 
perfectly (Fig. 3). For example, functions A to L (Table 1) each had $R^{2}>0.9999$. Although kinetic functions $\mathrm{M}$ to $\mathrm{R}$ (Table 1) did not fit the simulated data as well $\left(R^{2}=0.9919\right.$ to 0.9959 ) they may fit real dose-response curves and, therefore, were included in the analyses. The logarithmic function, while explaining about $79.4 \%$ of the variation in the simulated data, clearly did not fit the data as well as the kinetic functions (Fig. 3). The sum of 50 kinetic functions of the form $\mathrm{Y}=\mathrm{a}+\mathrm{b}(1-\exp (-\mathrm{cX}))$ (equation B from Table 1) that were generated, each with a different y-intercept, might represent a spike frequency output of 50 receptors of different sensitivity; this produced a sigmoid curve representing the dose-EAG signal (Fig. 4). This curve was fit best by functions I and J (Table 1), which are first order sequential formation functions (both $R^{2}>0.9999$ ). Similarly, the logistic dose-response curve $\mathrm{Y}=\mathrm{a} /\left(1+(\mathrm{X} / \mathrm{b})^{\mathrm{c}}\right)$ also gave $R^{2}>0.9999$. This shows that a summation of individual kinetic functions that are all convex can yield a sigmoid curve when plotted on a linear X scale (Fig. 4).

The kinetic formation functions (Table 1) describing various enzyme reactions from first order to third order were examined for their fit to the dose-response data from the literature, for comparison with the logtransformed linear regression $[\mathrm{Y}=\mathrm{a}+\mathrm{b} \ln (\mathrm{X})]$. As noted earlier, fit of a model function to insect sample sets is indicated by the adjusted $R^{2}$ (the closer to 1 , the better the fit), and will be referred to as $r^{2}$. Of 45 dose-response curves using EAG (voltage depolarization or spike frequency), all but one were explained best (highest $\mathrm{r}^{2}$ ) by kinetic functions. Of those 44 data sets, 36 were fit best by functions A-L and eight were fit best by functions $\mathrm{M}-\mathrm{R}$ (see supplementary material, Table $\mathrm{S} 1$ ). The average $r^{2}$ was $0.966 \pm 0.062( \pm \mathrm{SD})$ for functions A-L,

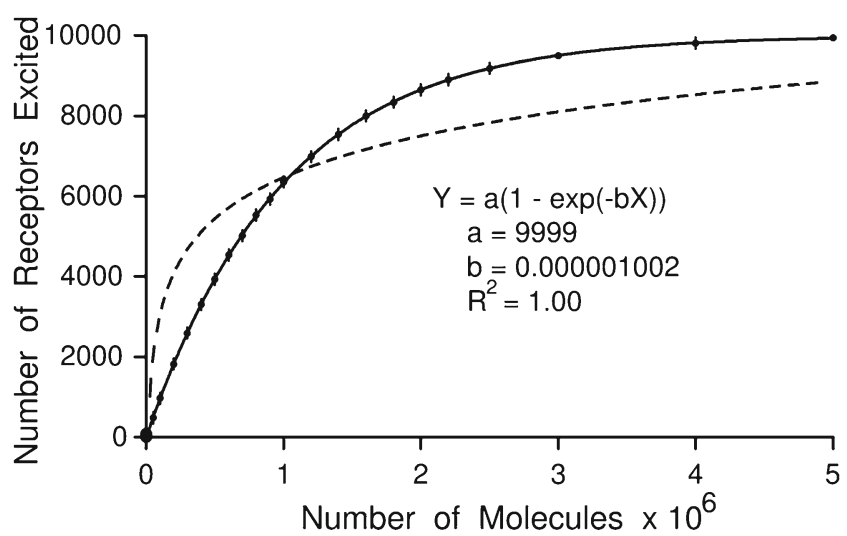

Fig. 3 The number of receptors excited, out of 10,000 theoretical receptors distributed among $10^{6}$ positions, in relation to the number of pheromone molecules striking an antenna. Many kinetic formation functions (A-L, Table 1) fit the relationship nearly perfectly (solid line, points mean of $n=8$ simulations $\pm 95 \% \mathrm{CL}$; function A shown, maximum $\mathrm{Y}=\mathrm{a}, \mathrm{X}$ at $50 \%$ maximum $\left.\mathrm{Y}=\ln (2) / \mathrm{b}, R^{2}>0.9999\right)$, while least squares regression of a logarithmic function $[\mathrm{Y}=\mathrm{a}+\mathrm{b} \ln (\mathrm{X}), \mathrm{a}=-14083, \mathrm{~b}=1487.54]$ fit less well (dashed line, $R^{2}=0.794$ )

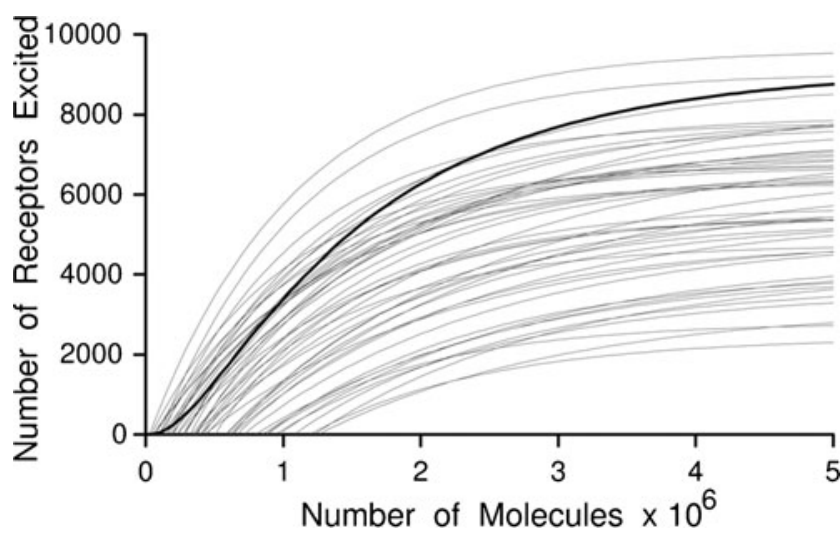

Fig. 4 Fifty kinetic functions $[Y=a+b(1-\exp (+c X))$, type $B]$ representing responses to molecule numbers by individual hypothetical receptors of varying sensitivity (thin lines) using different random values of $\mathrm{a}, \mathrm{b}$, and $\mathrm{c}$. The thick line represents the summation of the responses of the 50 curves and scaled for plotting (multiplying sums by 0.03 )

$0.927 \pm 0.100$ for $\mathrm{M}-\mathrm{R}$, and $0.745 \pm 0.202$ for the logarithmic function. Thus, kinetic functions A-L explained $22.1 \%$ more of the EAG variation than did the logarithmic regression. Of 21 dose-response curves from laboratory bioassays (orientation to source or other behavior), all were explained best by kinetic functions. Of these data sets, 16 were fit best by functions $\mathrm{A}-\mathrm{L}$ and five were best fit by functions M-R (Table S2, supplemental material). The average $r^{2}$ for functions A-L was highest at $0.912 \pm 0.149$, followed by functions $\mathrm{M}-\mathrm{R}$ at $0.803 \pm 0.272$, and least for the logarithmic function at $0.623 \pm 0.297$. Thus, functions A-L explained $28.7 \%$ more of the laboratory bioassay variation than did the logarithmic regressions. Similarly, of 23 dose-response curves using field catches, all but four were explained best by kinetic functions, and of these, 14 were fit best by functions $\mathrm{A}-\mathrm{L}$ and five were fit best by $\mathrm{M}-\mathrm{R}$ (Table S3, supplemental material). The average $r^{2}$ was $0.771 \pm 0.270$ for functions $\mathrm{A}-\mathrm{L}, 0.748 \pm 0.310$ for $\mathrm{M}-\mathrm{R}$, and $0.687 \pm 0.320$ for the logarithmic regressions. Thus, functions A-L explained $8.4 \%$ more of the catch variation than did the logarithmic regressions. The regression coefficients for the functions (Table 1) best fitting the various data sets from the literature are given in the footnotes of their corresponding table (Tables S1-3).

A logistic function $Y=a /\left(1+X / b^{c}\right)$, when applied to the EAG data sets (Table S1), would not fit in 14 of the cases, while of the 31 pairs in which kinetic formation and logistic functions could be fit, the average $r^{2}$ was 0.967 for kinetic functions $\mathrm{A}-\mathrm{L}$, compared to $r^{2}=0.817$ for the logistic ones ( $15 \%$ more variation explained by kinetic than logistic). The kinetic functions are also applicable to inhibitor dose-response curves that are less common. Tilden and Bedard (1988) used attractive pheromone-baited traps releasing the bark beetle inhibitor verbenone at $1,10,100$, and $1000 \mathrm{mg} /$ day, and obtained mean catches $(\mathrm{Y})$ of 8.6, 2.7, 1.5, and 0.4, respectively. A third-order kinetic decay function $\mathrm{Y}=\mathrm{a} /$ $\left(1+2 \mathrm{a}^{2} \mathrm{bX}\right)^{0.5}$, where $\mathrm{a}=22.5$ and $\mathrm{b}=0.0058$, gave $r^{2}=0.971$, 
a better fit than the logarithmic function $\left(r^{2}=0.490\right)$. In another experiment, they increased the relative release rate of aggregation pheromone by ten-fold, with the above dosages of verbenone, and caught means of 94.5, 65.9, 21.7, and 4.8, which were best fit by a kinetic decay function of variable order, $\mathrm{Y}=\left(\mathrm{a}^{1-\mathrm{c}}+\mathrm{bcX}-\mathrm{bX}\right)^{(1 /(1-\mathrm{c}))}$ where $\mathrm{a}=99.83, \mathrm{~b}=6.7 \mathrm{E}-5$, and $c=2.466$, giving an $r^{2}=0.999$ (compared to 0.925 for logarithmic regression).

Plotting Kinetic Formation Functions on Logarithmic X-axis Scales The function $\mathrm{Y}=\mathrm{a}(1-\exp (-\mathrm{bX}))$ (function A from Table 1), which was convex when plotted with linear $\mathrm{x}$ values (Fig. 3), was transformed into a sigmoid curve when plotted on a log scale (Fig. 5). As expected, the logarithmic curve (Fig. 3) became linear when plotted on a log scale (Fig. 5). As stated earlier, the composite of 50 convex curves plotted on a linear $\mathrm{x}$-scale gave a sigmoid curve (Fig. 4) that was also sigmoid when plotted on a log scale for the $\mathrm{X}$-axis (similar to sigmoid curve in Fig. 5 but shifted to the right, not shown).

Comparison of Dose-response Curves and EAR and EAR in the Field The catch of bark beetle Ips typographus (Fig. 6, data from Table S3) in response to increasing releases of aggregation pheromone component, cis-verbenol, with a constant release of 2-methyl-3-buten-2-ol, was well fit $\left(r^{2}=0.996\right)$ by the kinetic function $\mathrm{Y}=\mathrm{a}-\left(\mathrm{a}^{(1-\mathrm{c})}+\mathrm{bX}(\mathrm{c}-1)\right)^{(1 /(1-c))}$ (function E, Table 1). The EAR (Fig. 6) was calculated from this catch (on 10 baited traps), using function E and a blank trap catch totaling 36 (from 10 traps), with an estimated pipe trap silhouette of $0.125 \mathrm{~m}^{2}$. The EAR was converted to the twodimensional $\mathrm{EAR}_{\mathrm{c}}$ (Fig. 6) by using the SD (2.75 m, Byers et al. 1989) of the beetle's vertical flight distribution (Fig. 6). These results indicate that EAR and $\mathrm{EAR}_{\mathrm{c}}$ increase with

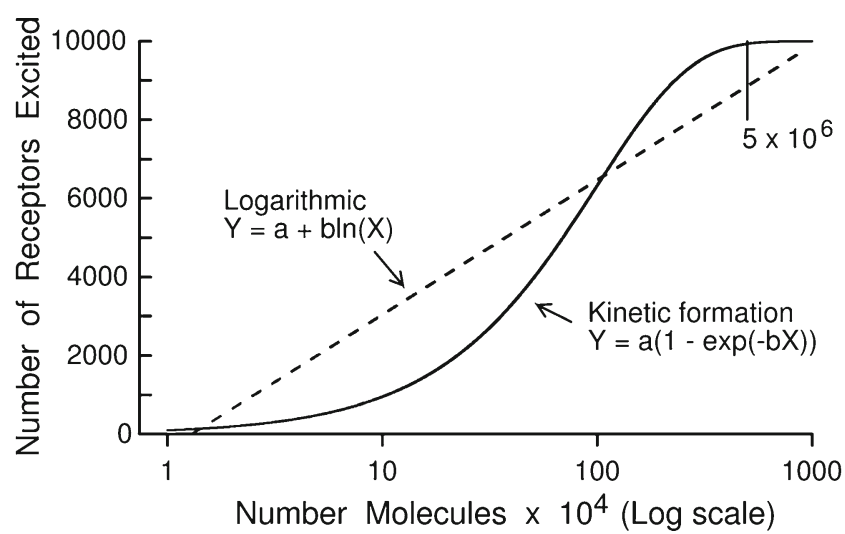

Fig. 5 A kinetic formation function fitting the simulated data, representing antennal response to varying concentrations of pheromone molecules (from Fig. 3), plotted on a log scale on the x-axis giving a sigmoid curve (solid line). The logarithmic function (from Fig. 3) when plotted on the log scale gives a straight line (dashed line). The cutoff of $5 \times 10^{6}$ molecules is indicated for comparison to Fig. 3

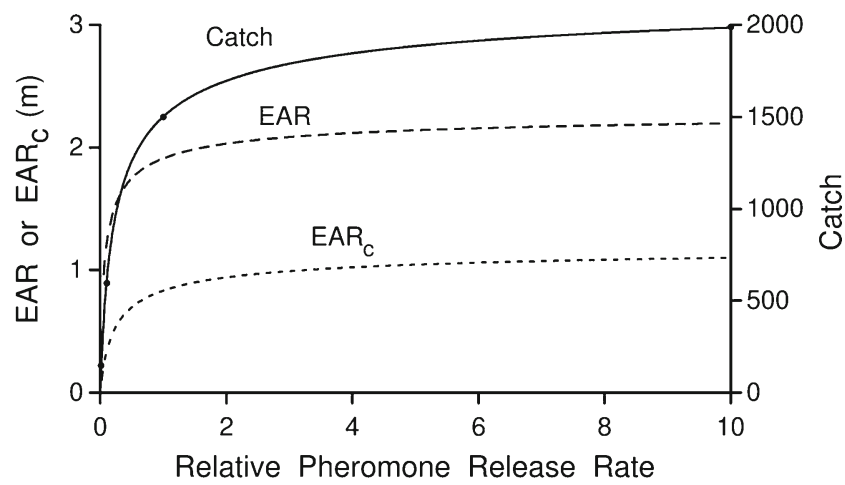

Fig. 6 Relationships between pheromone release rate $(0.01$ to $10 \mathrm{mg} /$ day cis-verbenol and $50 \mathrm{mg} /$ day 2-methyl-3-buten-2-ol) and catch of bark beetle Ips typographus (Schlyter et al. 1987) were fit by kinetic function E $\left[\mathrm{Y}=\mathrm{a}-\left(\mathrm{a}^{(1-\mathrm{c})}+\mathrm{bX}(\mathrm{c}-1)\right)^{(1 /(1-\mathrm{c}))}\right.$, where $\mathrm{a}=2257, \mathrm{~b}=2.445 \mathrm{E}-7$, and $\left.\mathrm{c}=3.1662, R^{2}=0.999\right]$. This function was used to calculate the corresponding spherical effective attraction radius (EAR) and circular $\mathrm{EAR}_{\mathrm{c}}$

semiochemical release rate in a similar relationship as the catch, providing there is no arrestment or disorientation caused by high levels of attractant.

\section{Discussion}

The number of olfactory sensilla per antenna ranges from a high of 59,000 in the saturniid moth Antheraea polyphemus (Meng et al. 1989) to about 1300 in the mosquito Culex pipiens (Hill et al. 2009), 860 in the wheat bug Eurygaster maura (Romani and Stacconi 2009), to 370 in females of the parasitoid wasp P. cerealellae (Onagbola and Fadamiro 2008). Pheromone molecules enter a pore in a sensillum, with each sensillum having many pores at densities of 2.8 pores $/ \mu \mathrm{m}^{2}$ in Pteromalus cerealellae wasps to $25-53$ pores $/ \mu \mathrm{m}^{2}$ in Coleophora moth spp., Onagbola and Fadamiro 2008; Faucheux 2011). Then, one or more of these molecules may couple with a membrane-bound receptor enzyme system (it is unknown how many per pore) and elicit a depolarizing spike (Hill et al. 2009; Leal 2005; Rützler and Zwiebel 2005; Sachse and Krieger 2011). Thus, my simulation model is simple, positing $10^{4}$ receptors and a few million molecules compared to natural systems. Although simple, the model (Fig. 1) captures the essential aspects of antennal reception of semiochemicals. It should not matter whether the receptors or the molecules (or both) are generated at random because the interaction of receptors and molecules is random in either case. However, the model only randomized the molecular paths that might strike a receptor position on the antenna on which a receptor occurs every 100 positions.

The output of the simulation model gave a convex curve that was not fit by the common logarithmic function $\left(R^{2}=0.79\right)$, but was fit nearly exactly by members of a family of non-linear kinetic functions (A-L Table $1, R^{2} \approx 1.00$ ). The functions model enzyme kinetic curves of either first, second, 
third, or variable order formations. A first-order formation would involve an enzymatic conversion of chemical A to B, depending on $\mathrm{C}$ (concentration of $\mathrm{A}$ ), according to $\mathrm{dC} / \mathrm{dt}=$ $\mathrm{kC}$, where $\mathrm{k}$ is a rate constant. In the functions $\mathrm{A}, \mathrm{C}, \mathrm{E}, \mathrm{I}, \mathrm{M}$, $\mathrm{O}$, and $\mathrm{Q}$, the parameter (a) represents the approximate asymptote of the response variable $(\mathrm{Y})$, while in functions $\mathrm{B}, \mathrm{D}$, $\mathrm{F}, \mathrm{H}, \mathrm{J}, \mathrm{N}, \mathrm{P}$, and R, the approximate asymptote is estimated by parameter (b). TableCurve 2D provides formulas for the dosage at $50 \%$ maximum response $\left(\mathrm{X}_{50}\right)$, except for functions $\mathrm{G}-$ $\mathrm{L}$, but these were not verified except for functions $\mathrm{A}$ : $\mathrm{X}_{50}=\ln (2) / \mathrm{b}$ and B: $\mathrm{X}_{50}=\ln (2) / \mathrm{c}$.

These kinetic functions are a sound basis for finding the best fitting curve through dose-response data, because these data are founded on antennal reception. Furthermore, it is well known that enzymes and odorant binding proteins (OBP) play a key role in olfactory reception of semiochemicals in the antennal sensilla, (1) by binding the molecules at cuticular pores and transporting them across the sensillar lymph fluid by diffusion to the dendritic membrane, (2) then by releasing the semiochemicals at, or interacting with, the transmembrane enzyme complexes (odorant receptors and non-specific ion channel proteins, and/or sensory neuron membrane proteins and/or G-protein pathways), and (3) by degrading the semiochemicals for removal (Leal 2005; Rützler and Zwiebel 2005; Sachse and Krieger 2011). There are obviously additional enzymatic reactions downstream that function in the interneuronal connections and brain processing that may cause the insect to move toward an odor source when walking or flying. These complex kinetic interactions in the insect justify using many kinetic functions of variable orders to obtain the best fits of particular data. Of the kinetic functions (A-L), the functions through the origin fit the catch data better (22 of 23), while non-origin functions fit the EAG data better (27 of 45), although there were a considerable variety of functions best fitting the data. Catch always drops to zero at zero dosage in the field, while EAG's have spontaneous activity that may better fit non-origin functions.

The 50 theoretical dose-response curves, each representing an individual receptor cell (Fig. 4), has a biological basis as demonstrated by O'Connell (1985), in which 35 pairs of neurons of the male cabbage looper moth each had similar but slightly different patterns of response to Z7-12:Ac or Z712:OH. Thus, it was possible to simulate a population of receptors with different sensitivities and convex dose-response curves on a linear scale and sum the responses (as an EAG would) to obtain a sigmoid dose-response curve. When this sigmoid curve, or the convex curve (Fig. 3), is plotted on a logarithmic dosage scale, then the resulting curves are sigmoid (Fig. 5). This suggests that dose-response curves for EAG (voltage or spike frequencies), behavioral bioassays in the laboratory, and catches in the field should generally be sigmoid curves approximated by kinetic formation functions.

In the curve fitting of the sample sets extracted from the literature, the $R^{2}$ values were adjusted by TableCurve 2D to show the amount of variance that each function explains in the population as inferred by the sample data. Adjusted $R^{2}$ (defined as $r^{2}$ here) adjusts the $\mathrm{R}^{2}$ downward depending on the number of sample points and model terms. The $R^{2}$ was adjusted because we are interested in fitting models that apply to insect species and not sample sets, and because models with more terms should not have an unfair advantage. All of the 20 studies reporting EAG dose-response curves, 12 of the 15 reports of behavioral assays, and two of the 14 reports of dose-response relationships, based on insect captures, reported results graphically (connection of data by straight lines). The remainder of the cited studies reported results are in the supplementary tables. None of these reports attempted to present their respective dose-response relationships through a descriptive model. However, Teale et al. (1991) and Byers (2007), using data from the literature (Byers 1988; Byers et al. 1988), report results for bark beetles assuming a logarithmic relationship between semiochemical dose and behavioral response. Therefore, there was some expectation that logarithmic regression would fit dose-response curves reasonably well.

In the analyses of the literature, all but one of the 45 doseresponse curves using EAG (voltage depolarization or spike frequency), all of the 21 laboratory bioassay curves, and all but four of 23 dose-catch curves were fit best by kinetic functions. The average $r^{2}$ for kinetic functions A-L was 0.903 for all examples, which explained $20.1 \%$ more of the variation on average than the logarithmic function (0.701). The highest $r^{2}$ fits of the kinetic functions A-L are to EAG dose-response curves (0.966), followed by laboratory bioassays $(0.910)$, and then field catches $(0.771)$. This trend may result because EAG directly reflects the antennal reception, while behavior in the laboratory is based not only on antennal reception but additional factors of physiological state, age, and condition that may influence the unexplained variation in response. Similarly, field catches not only depend on the antennal olfactory system and physiological condition, but have additional variation introduced by environmental variables such as temperature, wind turbulence, wind speed, and frequency of wind direction changes, as well as insect orientation distance. This may also explain why variation in $r^{2}$ (indicated by the SD of the mean $r^{2}$ ) among examples for EAG (0.062), bioassay (0.149), and catch (0.270) were progressively larger.

While most dose-response curves involving positive responses were fit by kinetic formation functions, it is likely that kinetic functions in the decay form can be fit to dose-response curves of pheromone inhibitors. Although there are few examples of such data, Tilden and Bedard (1988) reported two sets of results demonstrating diminishing trap catch of the bark beetle $D$. brevicomis to aggregation pheromone when the dosage of the inhibitor verbenone was increased. Visual inspection of the kinetic decay functions indicate they fit 
better than the logarithmic regression, and the higher $r^{2}$ for the kinetic functions supports this.

Although the kinetic functions provided good fit to most of the data sets examined, there were exceptions that were better fit by a logarithmic regression. Studies with dosages that cover a limited range on a log scale could show an exponential-like increasing curve (at lower dosages), a straight line (in the middle of dose-response curves), or a curve of diminishing increase (at the highest saturating dosages). A few studies with a very narrow range of dosages (e.g., EAG responses over only a 10 -fold dosage range) showing logarithmic relationships (Ma et al. 1980; Manabe and Nishino 1985) were not included in the analyses. While only five data sets out of 89 were found to be best fit by the logarithmic regression, in two of these cases the dosages only ranged over two orders of magnitude, which may have coincided with the linear portion of the sigmoid curve.

Van Giessen et al. (1994) proposed that a logistic function best fit the EAG data of pea aphid, Acyrthosiphon pisum, in response to plant aldehydes and alcohols from $\mathrm{C} 4-\mathrm{C} 8$. While this study proposed sigmoid functions, they did not describe methods for fitting the function to data nor how well the logistic function fit the experimental data. Sans et al. (1997) do not report how the logistic function of Van Giessen et al. (1994) was fit to EAG dose responses of two attractive pheromone blends for male Mediterranean corn borer moths. Furthermore, logistic terms for the best fitting functions were not reported nor were the $R^{2}$ fit values. Using TableCurve 2D, a logistic dose-response equation could be fit to the EAG data sets (Table S1) in only 31 of 45 cases. Of these possible comparisons, the kinetic functions $\mathrm{A}-\mathrm{L}$ fit better and explained $15 \%$ more of the variation than did the logistic regression. Thus, non-linear regression showed kinetic functions fit the EAG dose-response data better than logarithmic and a common dose-response logistic function.

The utility of kinetic functions in describing insect response to pheromone in the field was demonstrated. Therefore, function $\mathrm{E}$ was used to predict catch of bark beetle Ips typographus in response to cis-verbenol releases (Table S3, Schlyter et al. 1987) and converted this to a spherical EAR (effective attraction radius) and circular $\mathrm{EAR}_{\mathrm{c}}$ (Fig. 6). As release of pheromone is increased, the EAR and $\mathrm{EAR}_{\mathrm{c}}$ have similar relationships to catch and, thus, they increase according to a kinetic function. However, extension of the EAR and $\mathrm{EAR}_{\mathrm{c}}$ at higher dosages may not be appropriate in many cases. For example, whereas bark beetles are attracted to thousands of conspecifics in a tree, male moths respond to single females. If dosage is increased beyond a certain level, then catch of moths begins to decline (Baker and Roelofs 1981; Byers 2007, 2012b). Thus, the EAR and $\mathrm{EAR}_{\mathrm{c}}$ cannot be increased indefinitely by increasing dosage because male moths may "conclude" that a female is in the vicinity well before they reach the source of unnaturally high concentrations of pheromone. Another consideration is that, given an initial insect population density, increasing EAR or $\mathrm{EAR}_{\mathrm{c}}$ in traps causes increased competition among the traps (and calling sex) and will result in diminished increases in catch despite large increases in costs for pheromone (Byers 2012b).

Results of the conceptual simulations reported herein, in combination with the generally good fit of experimental data to the kinetic functions, suggest these functions have wide applicability in the description of semiochemical dose-response relationships. The use of kinetic formation functions for attractants (and probably kinetic decay functions for inhibitors) will allow more accurate relationships to be calculated for EAG and behavioral responses involving a wide range of semiochemical release rates.

Acknowledgments I thank Dr. Dale Spurgeon for helpful reviews of earlier versions of the manuscript. Mention of trade names or commercial products in this article is solely for the purpose of providing specific information and does not imply recommendation or endorsement by the U.S. Department of Agriculture. USDA is an equal opportunity provider and employer.

\section{References}

Al Abassi S, Birkett MA, Pettersson J, Pickett JA, Wadhams LJ, Woodcock CM (2000) Response of the seven-spot ladybird to an aphid alarm pheromone and an alarm pheromone inhibitor is mediated by paired olfactory cells. J Chem Ecol 26:1765-1771

Anderson P, Hilker M, Hansson BS, Bombosh S, Klein B, Schildknecht H (1993) Oviposition deterring components in larval frass of Spodoptera littoralis (Boisd.) (Lepidoptera: noctuidae): a behavioural and electrophysiological evaluation. J Insect Physiol 39:129-137

Baker TC, Roelofs WL (1981) Initiation and termination of oriental fruit moth male response to pheromone concentrations in the field. Environ Entomol 10:211-218

Byers JA (1983) Sex-specific responses to aggregation pheromone: regulation of colonization density in the bark beetle Ips paraconfusus. $\mathrm{J}$ Chem Ecol 9:129-142

Byers JA (1988) Novel diffusion-dilution method for release of semiochemicals: testing pheromone component ratios on western pine beetle. J Chem Ecol 14:199-212

Byers JA (2007) Simulation of mating disruption and mass trapping with competitive attraction and camouflage. Environ Entomol 36:13281338

Byers JA (2009) Modeling distributions of flying insects: effective attraction radius of pheromone in two and three dimensions. $\mathrm{J}$ Theor Biol 256:81-89

Byers JA (2011) Analysis of vertical distributions and effective flight layers of insects: three-dimensional simulation of flying insects and catch at trap heights. Environ Entomol 40:1210-1222

Byers JA (2012a) Estimating insect flight densities from attractive trap catches and flight height distributions. J Chem Ecol 38:592601

Byers JA (2012b) Modelling female mating success during mass trapping and natural competitive attraction of searching males or females. Entomol Exp Appl 145:228-237

Byers JA, Anderbrant O, Löfqvist J (1989) Effective attraction radius: a method for comparing species attractants and determining densities of flying insects. J Chem Ecol 15:749-765 
Byers JA, Birgersson G, Löfqvist J, Bergström G (1988) Synergistic pheromones and monoterpenes enable aggregation and host recognition by a bark beetle, Pityogenes chalcographus. Naturwissenschaften 75:153-155

Byers JA, Wood DL, Browne LE, Fish RH, Piatek B, Hendry LB (1979) Relationship between a host plant compound, myrcene and pheromone production in the bark beetle, Ips paraconfusus. J Insect Physiol 25:477-482

Chuman T, Guss PL, Doolittle RE, Mclaughlin JR, Krysan JL, Schalk JM, Tumlinson JH (1987) Identification of female-produced sex pheromone from banded cucumber beetle, Diabrotica balteata LeConte (Coleoptera: Chrysomelidae). J Chem Ecol 13:16011616

Delorme JD, Payne TL (1990) Antennal olfactory responses of black turpentine beetle, Dendroctonus terebrans (Olivier), to bark beetle pheromones and host terpenes. J Chem Ecol 16:1321-1329

Dickens JC, Oliver JE, Mastro VC (1997) Response and adaptation to analogs of disparlure by specialist antennal receptor neurons of gypsy moth, Lymantria dispar. J Chem Ecol 23:2197-2210

Dolzer J, Fischer K, Stengl M (2003) Adaptation in pheromone-sensitivie trichoid sensilla of the hawkmoth Manduca sexta. J Exp Biol 206:1575-1588

Faucheux MJ (2011) Antennal sensilla in adult males of five species of Coleophora (Coleophoridae): considerations on their structure and function. Nota Lepid 34:93-101

Gemeno C, Leal WS, Mori K, Schal C (2003) Behavioral and electrophysiological responses of the brownbanded cockroach, Supella longipalpa, to stereoisomers of its sex pheromone, supellapyrone. J Chem Ecol 29:1797-1811

Grant AJ, Lanier GN (1982) Electroantennogram responses of Scolytus multistriatus (Coleoptera: Scolytidae) to its pheromone components and to associated compounds. J Chem Ecol $8: 1333-1344$

Hilbur Y, Bengtsson M, Löfqvist J, Biddle A, Pillon O, Plass E, Francke W, Hallberg E (2001) A chiral sex pheromone system in the pea midge, Contarinia pisi. J Chem Ecol 27:1391-1407

Hill SR, Hansson B, Ignell R (2009) Characterization of antennal trichoid sensilla from female southern house mosquito, Culex quinquefasciatus Say. Chem Senses 34:231-252

Jewett DK, Brigham DL, Bjostad LB (1996) Hesperophylax occidentalis (Trichoptera: Limnephilidae): electroantennogram structure-activity study of sex pheromone component 6-methylnonan-3-one. J Chem Ecol 22:123-137

Leal WS (2005) Pheromone reception. Topics Curr Chem 240:1-36

Ma M, Hummel HE, Burkholder WE (1980) Estimation of single furniture carpet beetle (Anthrenus flavipes LeConte) sex pheromone release by dose-response curve and chromatographic analysis of pentafluorobenzyl derivative of (Z)-3-decenoic acid. J Chem Ecol 6:597-607
Manabe S, Nishino C (1985) Interaction of olfactory stimulants with receptors: affinity and intrinsic activity of the stimulants to the receptors. Comp Biochem Physiol 82A:193-200

Meng LZ, Wu CH, Wicklein M, Kaissling KE, Bestmann HJ (1989) Number and sensitivity of three types of pheromone receptor cells in Antheraea pernyi and A. polyphemus. J Comp Physiol A 165:139146

Moore I (1981) Biological amplification for increasing electroantennogram discrimination between two female sex pheromones of Spodoptera littoralis (Lepidoptera: Noctuidae). J Chem Ecol 7:791-798

O'connell RJ (1985) Responses to pheromone blends in insect olfactory receptor neurons. J Comp Physiol A 156:747-761

Onagbola EO, Fadamiro HY (2008) Scanning electron microscopy studies of antennal sensilla of Pteromalus cerealellae (Hymenoptera: Pteromalidae). Micron 39:526-535

Preiss R, Priesner E (1988) Responses of male codling moths (Laspeyresia pomonella) to codlemone and other alcohols in a wind tunnel. J Chem Ecol 14:797-813

Romani R, Stacconi MVR (2009) Mapping and ultrastructure of antennal chemosensilla of wheat bug Eurygaster maura. Insect Sci 16:193203

Rützler M, Zwiebel LJ (2005) Molecular biology of insect olfaction: recent progress and conceptual models. J Comp Physiol A 191:777-790

Sachse S, Krieger J (2011) Olfaction in insects: the primary processes of odor recognition and coding. E-neuroforum 2:49-60

Sans A, Riba M, Eizaguirre M, Lopez C (1997) Electroantennogram, wind tunnel and field response of male Mediterranean corn borer, Sesamia nonagrioides, to several blends of its sex pheromone components. Entomol Exp Appl 82:121-127

Schal C, Burns EL, Jurenka A, Blomquist GJ (1990) A new component of the female sex pheromone of Blattella germanica (L.) (Dictyoptera: Blattellidae) and interaction with other pheromone components. J Chem Ecol 16:1997-2008

Schlyter F, Löfqvist J, Byers JA (1987) Behavioural sequence in attraction of the bark beetle Ips typographus to pheromone sources. Physiol Entomol 12:185-196

Teale SA, Webster FX, Zhang A, Lanier GN (1991) Lanierone: a new pheromone component from Ips pini (Coloeptera: Scolytidae) in New York. J Chem Ecol 17:1159-1176

Tilden PE, Bedard WD (1985) Field response of Dendroctonus brevicomis to exo-brevicomin, frontalin, and myrcene released at two proportions and three levels. J Chem Ecol 11:757-766

Tilden PE, Bedard WD (1988) Effect of verbenone on response of Dendroctonus brevicomis to exo-brevicomin, frontalin, and myrcene. J Chem Ecol 14:113-122

Van Giessen WA, Fescemyer HW, Burrows PM, Peterson JK, Barnett OW (1994) Quantification of electroantennogram responses of the primary rhinaria of Acyrthosiphon pisum (Harris) to $\mathrm{C}_{4}-\mathrm{C}_{8}$ primary alcohols and aldehydes. J Chem Ecol 20:909-927 


\section{Modeling and Regression Analysis of Semiochemical Dose-Response Curves of Insect Antennal Reception and Behavior}

\section{John A. Byers}

US Arid-Land Agricultural Research Center, USDA-ARS, 21881 North Cardon Lane,

Maricopa, Arizona 85138, USA, e-mail: john.byers@ars.usda.gov

\section{Supplementary Tables S1 - S3 and references:}

Table S1. Logarithmic $[\mathrm{Y}=\mathrm{a}+\mathrm{b} \ln (\mathrm{X})]$ and non-linear (kinetic formation A-R) regressions describing the relationship between dosage of semiochemical $(\mathrm{X})$ and electroantennographic $(\mathrm{EAG})$ response for various insects $(\mathrm{Y})$.

\begin{tabular}{|c|c|c|c|c|}
\hline Insect species - attractant & Dosages (X) & EAG (Y) & $\begin{array}{l}\text { Logarithmic } \\
\text { adjusted } \mathrm{R}^{2}\end{array}$ & Kinetic formation A-R (adjusted $\left.\mathrm{R}^{2}\right)^{\mathrm{a}}$ \\
\hline 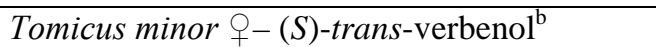 & $10,100,1000,10000$ & $62,145,162,179$ & 0.515 & E (0.970); G (0.964); C (0.960); R (0.981) \\
\hline T. minor $\hat{\sigma}-(S)$-trans-verbenol ${ }^{\mathrm{b}}$ & $10,100,1000,10000$ & $44,131,170,187$ & 0.691 & E (0.996); C (0.978); B (0.965); R (0.999) \\
\hline Dendroctonus micans $-(+)$-ipsdienol ${ }^{\mathrm{C}}$ & $0.1,1,10,100,1000$ & $12,24,36.2,51.1,54.2$ & 0.945 & G (0.986); K (0.986); F (0.966); R (0.986) \\
\hline D. micans - exo-brevicomin ${ }^{\mathrm{c}}$ & $0.5,5,50,500$ & $26.1,46,56.2,60$ & 0.717 & E (0.999); B (0.968); R (0.999); P (0.990) \\
\hline $\begin{array}{l}\text { Hesperophylax occidentalis males- 6- } \\
\text { methylnonan-3-one }^{\mathrm{d}}\end{array}$ & $0.1,1,10,100,1000$ & $0.48,0.60,0.74,0.85,0.92$ & 0.983 & F (0.999); E (0.990); K (0.905); R (0.939) \\
\hline Mamestra suasa A cell- Z11-16:Ac ${ }^{\mathrm{e}}$ & $1,10,100,1000,10000$ & $5.5,8.3,21.5,44.3,66.0$ & 0.867 & F (0.992); G (0.971); K (0.971); R (0.978) \\
\hline M. suasa B cell- Z9-14:Ac ${ }^{\mathrm{e}}$ & $1,10,100,1000,10000$ & $6.8,15.2,22.2,50.6,84.4$ & 0.802 & G (0.999); K (0.996); F (0.968); R (0.964) \\
\hline Microplitis croceipes - Z3-6: $\mathrm{Ac}^{\mathrm{f}}$ & $0.1,1,10,100$ & $7.1,17.1,49.2,102.9$ & 0.743 & $\mathrm{~B}(0.992) ; \mathrm{E}(0.956) ; \mathrm{C}(0.938) ; \mathrm{R}(0.996)$ \\
\hline M. croceipes - benzaldehyde $^{f}$ & $0.1,1,10,100$ & $3.3,17.6,59.4,112.5$ & 0.838 & E (0.992); B (0.987); C (0.979); R (0.995) \\
\hline Spodoptera littoralis - Z,E-9,11-14:Ac ${ }^{\mathrm{g}}$ & $0.2,2,20,200$ & $2.27,2.95,6.41,6.70$ & 0.657 & B (0.994); E (0.667); N (0.924); P (0.924) \\
\hline S. littoralis - two components ${ }^{\mathrm{g}}$ & $0.2,2,20,200$ & $4.01,4.78,8.22,7.26$ & 0.184 & B (0.845); E (0.313); P (0.647); N (0.647) \\
\hline Colopterus truncates - triene 2 , female ${ }^{\mathrm{h}}$ & $0.1,1,10,100$ & $1.24,2.47,3.65,4.00$ & 0.857 & E (0.978); B (0.961); R (0.998); N (0.997) \\
\hline 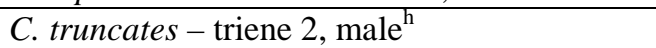 & $0.1,1,10,100$ & $1.07,1.27,1.71,1.98$ & 0.944 & B (0.963); R (0.999); N (0.992); P (0.992) \\
\hline S. littoralis - eugenol ${ }^{\mathrm{i}}$ & $1,10,100,1000,10000$ & $90.4,138.6,171.1,188,233.7$ & 0.956 & K (0.816); F (0.833); R (0.685) \\
\hline S. littoralis - nonanal ${ }^{\mathrm{i}}$ & $1,10,100,1000$ & $72.3,108.4,259,474.7$ & 0.755 & B (0.997); E (0.857); C (0.773); R (0.999) \\
\hline S. littoralis - acetophenone $\mathrm{i}^{\mathrm{i}}$ & $1,10,100,1000$ & 73.5, 83.3, 210.6, 291.4 & 0.764 & $\mathrm{~B}(0.996) ; \mathrm{P}(0.985) ; \mathrm{N}(0.985) ; \mathrm{R}(0.973)$ \\
\hline Coccinella septempunctata - (E)- $\beta$-farnesene ${ }^{j}$ & $10,100,1000,10000$ & $9.3,25.3,55.1,52.9$ & 0.619 & B (0.993); C (0.933); E (0.926); P (0.931) \\
\hline C. septempunctata - $\beta$-caryophyllene ${ }^{j}$ & $1,10,100,1000,10000$ & $4.9,7.7,19.9,39.9,68$ & 0.823 & G (0.981); K (0.978); F (0.973); R (0.951) \\
\hline Contarinia pisi - 2S12S-diacetoxytridecane ${ }^{\mathrm{k}}$ & $0.1,1,10,100$ & $0.23,0.25,0.52,0.76$ & 0.746 & B (0.997); N (0.993); P (0.993); R (0.988) \\
\hline
\end{tabular}




\begin{tabular}{|c|c|c|c|c|}
\hline Agrotis segetum - Z5-10:OAc, Sweden $^{\top}$ & $0.01,0.1,1,10,100$ & $16.9,32.4,55.8,99.1,74.3$ & 0.540 & F (0.653); B (0.653); J (0.645); N (0.569) \\
\hline A. segetum - Z5-10:OAc, Zimbabwe & $0.01,0.1,1,10,100$ & $4.3,29.1,67.4,127.5,122.2$ & 0.857 & K (0.994); G (0.992); D (0.946); N (0.924) \\
\hline A. segetum - Z7-12:OAc, Sweden & $0.01,0.1,1,10,100$ & $8.9,18.1,39.9,68.6,59.7$ & 0.747 & D (0.919); F (0.917); B (0.916); N (0.870) \\
\hline A. segetum - Z7-10:OAc, Zimbabwe ${ }^{I}$ & $0.01,0.1,1,10,100$ & $0.3,5.6,45.2,119.3,114.1$ & 0.773 & A (0.997); F (0.995); B (0.994); P (0.935) \\
\hline Scolytus multistriatus $-\alpha$-multistriatin ${ }^{\mathrm{m}}$ & $0.5,5,50,500,1000$ & $45.2,54.5,69.3,97.9,100.3$ & 0.920 & D (0.967); F (0.967); B (0.958); R (0.967) \\
\hline S. multistriatus - 4-methyl-3-heptanol ${ }^{\mathrm{m}}$ & $5,50,250,500,760,1905$ & $\begin{array}{l}30.3,37.1,58.7,74.2,93.8, \\
98.8\end{array}$ & 0.796 & B (0.970); F (0.962); J (0.941); P (0.946) \\
\hline Agrotis segetum - Z5-10:OAc ${ }^{\mathrm{n}}$ & $0.1,1,10,100,1000$ & $6.5,74.6,77.9,92.7,87.2$ & 0.314 & $\mathrm{~A}(0.928) ; \mathrm{D}(0.909) ; \mathrm{E}(0.855) ; \mathrm{M}(0.866)$ \\
\hline Dendroctonus ponderosae $q-$ exo-brevicomin ${ }^{\circ}$ & $0.01,0.1,1,10,100$ & $39.3,60,88.4,118.7,130.5$ & 0.970 & F (0.985); K (0.954); R (0.966) \\
\hline D. ponderosae $\hat{0}-$ exo-brevicomin ${ }^{0}$ & $0.01,0.1,1,10,100$ & $23.3,25.7,71.8,101.8,121.9$ & 0.964 & F (0.998); D (0.947); R (0.985); N (0.947) \\
\hline D. terebrans ${ }_{+}-$endo-brevicomin ${ }^{\mathrm{P}}$ & $0.005,0.05,0.5,5,50$ & $27.6,39,71.6,131.8,130.4$ & 0.832 & B (0.990); D (0.990); F (0.990); P (0.956) \\
\hline D. terebrans $\hat{\sigma}-$ endo-brevicomin ${ }^{\mathrm{p}}$ & $0.005,0.05,0.5,5,50$ & $29.3,51.4,76.4,110,201.4$ & 0.793 & K (0.958); F (0.854); D (0.842); R (0.850) \\
\hline D. terebrans ${ }_{+}$- turpentine $\mathrm{p}^{\mathrm{P}}$ & $0.005,0.05,0.5,5,50$ & $18.4,17,29.8,57.4,61.6$ & 0.768 & F (0.991); D (0.991); J (0.986); N (0.971) \\
\hline D. terebrans $\hat{\sigma}-$ turpentine $^{\mathrm{P}}$ & $0.005,0.05,0.5,5,50$ & $19.8,31.9,31.9,78.7,86.5$ & 0.744 & J (0.923); F (0.922); B (0.920); N (0.858) \\
\hline Lymantria dispar - (+)-disparlure ${ }^{\mathrm{q}}$ & $0.5,5,50,500,5000$ & $12.4,33.8,119.4,200.6,375.2$ & 0.839 & G (0.997); K (0.997); F (0.897); R (0.862) \\
\hline Manduca Sexta - bombykal ${ }^{\mathrm{r}}$ & $1,10,100,1000,10000$ & $0.14,0.19,0.38,0.59,0.86$ & 0.909 & F (0.988); G (0.913); R (0.921) \\
\hline Coleomegilla maculata + - Z3-6: $\mathrm{OH}^{\mathrm{s}}$ & $1,10,100,1000$ & $1.18,1.27,2.15,4.79$ & 0.412 & B (0.999); N (0.999), P (0.999); R (0.999) \\
\hline C. maculata $\widehat{\widehat{O}}-\mathrm{Z} 3-6: \mathrm{OH}^{\mathrm{s}}$ & $1,10,100,1000$ & $1.06,1.08,1.87,2.53$ & 0.713 & B (0.992); P (0.984); N (0.984); R (0.978) \\
\hline C. maculata $\bigcirc-$ aphid pheromone ${ }^{\mathrm{s}}$ & $1,10,100,1000$ & $1.21,1.29,2.89,3.63$ & 0.728 & B (0.989); N (0.965); P (0.965); R (0.943) \\
\hline C. maculata $\hat{O}^{\lambda}-$ aphid pheromone $\mathrm{s}^{\mathrm{s}}$ & $1,10,100,1000$ & $0.99,1.11,2.31,2.16$ & 0.339 & B (0.906); E (0.370); P (0.735); N (0.735) \\
\hline Crysoperla carnea $\bigcirc$ - aphid pheromone ${ }^{\mathrm{s}}$ & $1,10,100,1000$ & $0.69,1.92,4.65,6.64$ & 0.945 & E (0.985); B (0.965); R (0.998); P (0.988) \\
\hline C. carnea $\hat{o}-$ aphid pheromone ${ }^{\mathrm{s}}$ & $1,10,100,1000$ & $0.61,1.92,6.33,5.44$ & 0.371 & E (0.919); A (0.917); I (0.916); P (0.777) \\
\hline Ectomyelois ceratoniae $\delta^{\lambda}-$ trienal $^{\mathrm{t}}$ & $0.01,0.1,1,10$ & $1.03,29.89,62.09,77.57$ & 0.945 & E (0.988); C (0.979); R (0.999); Q (0.987) \\
\hline Anthonomus grandis $\hat{\delta}-1$-hexenol ${ }^{\mathrm{u}}$ & $0.1,1,10,100,1000$ & $3.82,12,39.27,91.09,120$ & 0.897 & F (0.998); E (0.987); D (0.982); R (0.997) \\
\hline A. grandis g $_{-1}$-hexenol ${ }^{\mathrm{u}}$ & $0.1,1,10,100,1000$ & $\begin{array}{l}2.7,13.04,27.72,103.26 \\
114.1\end{array}$ & 0.778 & F (0.988); B (0.988); D (0.988); N (0.945) \\
\hline
\end{tabular}

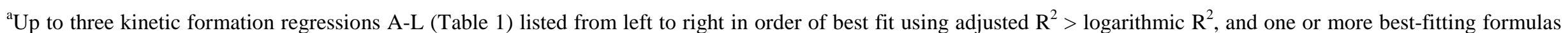
$\mathrm{M}-\mathrm{R}$, (if $\mathrm{R}^{2}$ of formation functions < logarithmic $\mathrm{R}^{2}$ then only the top two formulas of each category are shown).

${ }^{\mathrm{b}}$ Lanne et al. (1987), Coleoptera: Curculionidae, Fig. 4 ( $\left.\mu \mathrm{g}\right)$ female, eq. $\mathrm{E}: \mathrm{a}=175.7, \mathrm{~b}=5.46 \mathrm{E}-5, \mathrm{c}=2.36$; male, eq. E: $\mathrm{a}=189.7$, b = 5.04E-6, c $=2.68$.

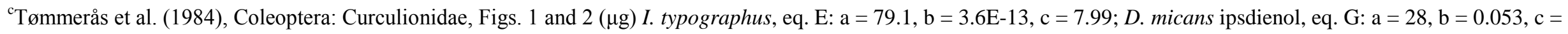
24.76, $\mathrm{d}=0.372 ;$ D. micans exo-brevicomin, eq. $\mathrm{E}: \mathrm{a}=63.1, \mathrm{~b}=4.43 \mathrm{E}-5, \mathrm{c}=3.62$.

${ }^{\mathrm{d} J e w e t t}$ et al. (1996), Trichoptera: Limnephilidae, Fig. $2(\mu \mathrm{g})$ eq. F: $\mathrm{a}=0.438, \mathrm{~b}=0.707, \mathrm{c}=9.51, \mathrm{~d}=8.24$.

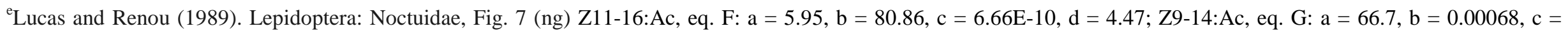
17.77, $d=0.0328$. 
${ }^{\mathrm{f}} \mathrm{Li}$ et al. (1992), Hymenoptera: Braconidae, Fig. 2C, D ( $\left.\mu \mathrm{g}\right)$ Z3-6:Ac, eq. B: $\mathrm{a}=9.06, \mathrm{~b}=94.1$, c $=0.0564$; benzaldehyde, eq. E: a $=159.5$, b = 5.42E-8, c = 3.856.

${ }^{\text {g} M o o r e ~(1981), ~ L e p i d o p t e r a: ~ N o c t u i d a e, ~ F i g . ~} 2(\mu \mathrm{g})$ Z,E-9,11:Ac, eq. B: a = 2.08, b = 4.68, c = 0.119; two components, eq. B: a $=3.73$, b $=4.024$, c $=0.188$.

${ }^{\mathrm{h}}$ Cossé and Bartelt (2000), Coleoptera: Nitidulidae, Fig. 4 ( $\left.\mu \mathrm{g}\right)$ female, eq. R: eq. R: a =0.847, b = 3.39, c $=0.012$; male eq. R: a $=1.039$, b $=0.076$, c $=0.264$.

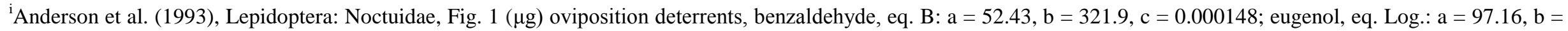
14.59; nonanal, eq. $\mathrm{B}: \mathrm{a}=76.6, \mathrm{~b}=398.7, \mathrm{c}=0.0062$; acetophenone, eq. $\mathrm{B}$ : $\mathrm{a}=66.97, \mathrm{~b}=224.7, \mathrm{c}=0.01$.

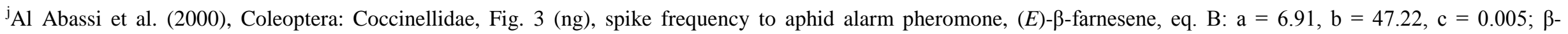
caryophyllene, eq. $\mathrm{G}$ : $\mathrm{a}=49.18, \mathrm{~b}=0.00056, \mathrm{c}=19.02, \mathrm{~d}=0.00425$.

${ }^{k}$ Hilbur et al. (2001), Diptera: Cecidomyiidae, Fig. $5(\mu \mathrm{g})$ sex pheromone eq. $\mathrm{B}: \mathrm{a}=0.218, \mathrm{~b}=0.543, \mathrm{c}=0.081$.

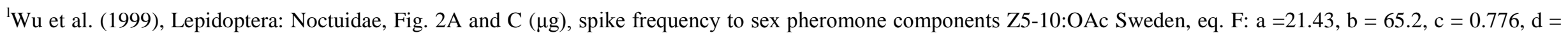

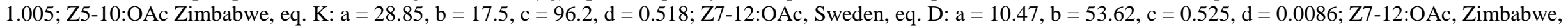
eq. $A: a=117.04, b=0.493$.

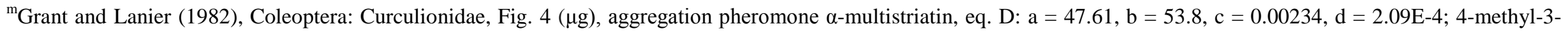
heptanol, eq. $\mathrm{B}: \mathrm{a}=29.02, \mathrm{~b}=72.58, \mathrm{c}=0.00222$.

${ }^{\mathrm{n}}$ Valeur et al. (2000), ; Lepidoptera: Noctuidae, Fig. 4 (ng), neuron spike frequency to four component sex pheromone, eq. A: a = 86.49, b = 1.73.

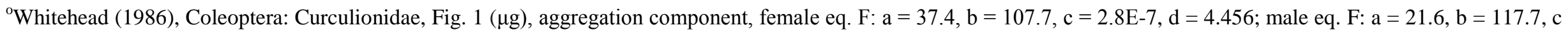
$=1.58 \mathrm{E}-7, \mathrm{~d}=4.382$.

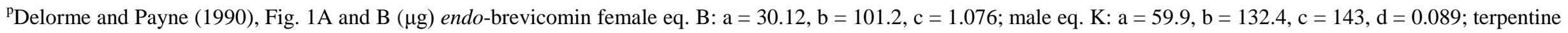
- female, eq. $\mathrm{F}: \mathrm{a}=16.96, \mathrm{~b}=44.64, \mathrm{c}=0.217, \mathrm{~d}=1.31$; male, eq. $\mathrm{J}: \mathrm{a}=25.7, \mathrm{~b}=60.8, \mathrm{c}=0.437, \mathrm{~d}=3.39$.

${ }^{\mathrm{q}}$ Dickens et al. (1997), Lepidoptera: Lymantriidae, Fig. 3 (ng) sex pheromone eq. G: $\mathrm{a}=244.2, \mathrm{~b}=0.0005$, c $=151.5$, $d=0.00039$.

${ }^{\mathrm{r}}$ Dolzer et al. (2003), Lepidoptera: Sphingidae, Fig. 7A (ng) sex pheromone eq. $\mathrm{F}$ : $\mathrm{a}=0.137, \mathrm{~b}=2.074, \mathrm{c}=7.4 \mathrm{E}-8$, $\mathrm{d}=15.58$.

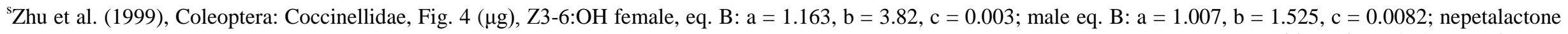

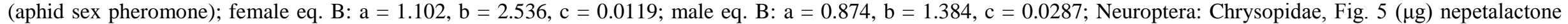
female eq. $\mathrm{R}: \mathrm{a}=0.561, \mathrm{~b}=7.037, \mathrm{c}=5.014 \mathrm{E}-4$; male eq. $\mathrm{A}: \mathrm{a}=5.9, \mathrm{~b}=0.04335$.

${ }^{\mathrm{t}}$ Todd et al. (1992), Lepidoptera: Pyralidae, Fig. $3(\mu \mathrm{g}),(Z, E)-9,11,13$-tetradecatrienal (trienal) eq. R: $\mathrm{a}=-5.276$, b = 89.65, c $=9.88 \mathrm{E}-4$. 


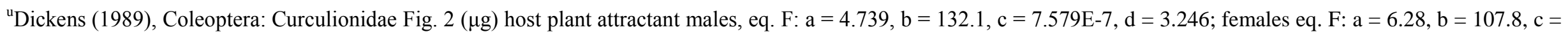
$0.0234, \mathrm{~d}=0.994$.

Table S2. Logarithmic $[\mathrm{Y}=\mathrm{a}+\mathrm{b} \ln (\mathrm{X})]$ and non-linear (kinetic formation A-R) regressions describing the relationship between dosage of pheromone $(\mathrm{X})$ and behavioral responses for various insects $(\mathrm{Y})$ in laboratory bioassays.

\begin{tabular}{|c|c|c|c|c|}
\hline Insect species - attractant & Dosages (X) & \% Response (Y) & $\begin{array}{c}\text { Logarithmic } \\
\text { adjusted } \mathrm{R}^{2}\end{array}$ & Kinetic formation A-R (adjusted $\left.\mathrm{R}^{2}\right)^{\mathrm{a}}$ \\
\hline Ips paraconfusus + - Ie and $\mathrm{Id}^{\mathrm{b}}$ & $0.89,8.9,89,890$ & $23,33,57,70$ & 0.928 & B (0.971); R (0.999); N (0.997); P (0.997) \\
\hline I. paraconfusus $\bigcirc-$ pheromone $^{\mathrm{c}}$ & $0.22,2.2,22,222,2222$ & $19,46,64,73,88$ & 0.927 & E (0.951); F (0.951); R (0.867) \\
\hline Dendroctonus brevicomis $q-$ pheromone $^{\mathrm{d}}$ & $0.02,0.2,2,20,200$ & $18.1,40.5,57.2,76.7,79.6$ & 0.912 & G (0.999); K (0.994); F (0.964); R (0.927) \\
\hline D. brevicomis $\delta^{\lambda}-$ pheromone $^{\mathrm{d}}$ & $0.02,0.2,2,20,200$ & $23.1,37,66.8,72.9,67.2$ & 0.590 & $\mathrm{D}(0.966) ; \mathrm{E}(0.679): \mathrm{P}(0.929) ; \mathrm{N}(0.929)$ \\
\hline Pityogenes chalcographus $-\mathrm{MD}^{\mathrm{e}}$ & $0.002,0.02,0.2,2,20,200$ & $29.9,39.9,57,60.6,70.2,73.8$ & 0.922 & L (0.997); E (0.941); F (0.938); R (0.927) \\
\hline P. chalcographus $-\mathrm{CH}^{\mathrm{e}}$ & $0.2,2,20,200$ & $23.7,47.2,70.2,73.8$ & 0.783 & B (0.988); E (0.959); C (0.814); N (0.999) \\
\hline Pityogenes bidentatus - pheromone ${ }^{\mathrm{f}}$ & $1,10,100,1000$ & $17.5,42.5,40,50$ & 0.304 & $\mathrm{E}(0.746) ; \mathrm{C}(0.736) ; \mathrm{N}(0.759)$ \\
\hline Ips pini - frass pheromone ${ }^{g}$ & $1,10,100,1000$ & $27.4,38.8,57.2,63.1$ & 0.902 & B (0.944); N (0.999); P (0.999); R (0.993) \\
\hline I. pini - aeration extract ${ }^{\mathrm{h}}$ & $1,10,100,1000$ & $30.4,54.3,70.6,77$ & 0.822 & E (0.996); B (0.953); R (0.999); P (0.988) \\
\hline Epiphyas postvittana - pheromone $^{\mathrm{i}}$ & $0.1,1,10,100$ & $24.2,58.3,86.7,76.7$ & 0.286 & B (0.934); C (0.859); E (0.856); N (0.886) \\
\hline Drosphila melanogaster - natural 7,11-27: $\mathrm{Hy}^{j}$ & $25,75,125,325,510,1000$ & $3.1,9.3,29.2,23.9,23.7,20.3$ & 0.119 & A (0.473); E (0.235); C (0.209); P (0.201) \\
\hline D. melanogaster $-7,11-27: \mathrm{Hy}^{j}$ & $140,200,400,500,1000$ & $2.2,15.6,16.1,17.3,17.7$ & 0.140 & B (0.968); J (0.797); F (0.264); N (0.031) \\
\hline D. melanogaster - natural 7-25: $\mathrm{Hy}^{j}$ & $220,230,285,515,1200$ & $2.3,5,9.3,18.9,19$ & 0.602 & J (0.969); B (0.965); F (0.964); N (0.735) \\
\hline D. melanogaster - 7-25: $\mathrm{Hy}^{\mathrm{j}}$ & $200,260,350,550,1550$ & $1.7,9.3,7.6,13.9,15.1$ & 0.456 & F (0.522); A (0.488); B (0.472); N (0.451) \\
\hline Supella longipalpa - 2R,4R-supelapyrone ${ }^{\mathrm{k}}$ & $1,3,10,30,100,1000$ & $15.4,50.3,59.7,90.1,93.7,94.2$ & 0.652 & L (0.951); H (0.908); K (0.857); R (0.901) \\
\hline S. longipalpa - 2S,4R-supelapyrone ${ }^{\mathrm{k}}$ & $3,9.9,30,99.9,300,999$ & $3.4,19.9,70.1,90.1,100.3,93.5$ & 0.745 & I (0.984); B (0.972); J (0.969); N (0.933) \\
\hline Cydia pomonella - codlemone & $0.01,0.1,1,10$ & $16.3,39,70.8,66$ & 0.544 & B (0.981); E (0.850); C (0.849); N (0.922) \\
\hline Blattella germanica - sex pheromone ${ }^{\mathrm{m}}$ & $0.1,1,5,10,50,100$ & $10.1,37.3,81.5,94.7,100.7,101$ & 0.862 & H (0.999); L (0.999); D (0.999); P (0.984) \\
\hline Agrotis segetum - pheromone blend $^{\mathrm{n}}$ & $1,10,100,1000,10000$ & $0.9,3,8.2,15.5,14.2$ & 0.804 & K (0.979); G (0.979); D (0.962); P (0.922) \\
\hline Aleochara curtula - Z7-21: $\mathrm{Hy}^{\mathrm{O}}$ & $0.01,0.1,1,10$ & $3.3,51.5,61.6,47.2$ & 0.000 & I (0.843); E (0.754); A (0.753); M (0.538) \\
\hline Blattella germanica - pheromone $\mathrm{p}^{\mathrm{p}}$ & $3.2,10,32,100,316,1000$ & $0.08,0.17,0.4,0.45,0.54,0.51$ & 0.791 & E (0.953); C (0.948); L (0.932); N (0.945) \\
\hline
\end{tabular}

${ }^{\mathrm{a}} \mathrm{Up}$ to three kinetic formation regressions A-L (Table 1) listed from left to right in order of best fit using adjusted $\mathrm{R}^{2}>$ logarithmic $\mathrm{R}^{2}$, and one or more best-fitting formulas $\mathrm{M}-\mathrm{R}$, (if $\mathrm{R}^{2}$ of formation functions < logarithmic $\mathrm{R}^{2}$ then only the top two formulas of each category are shown).

${ }^{\mathrm{b}}$ Byers et al. (1979), Coleoptera: Curculionidae, Table 2 (ng/min); ipsenol (Ie) and ipsdienol (Id), eq. R: a = 21.1, b = 56.07, c = 1.15E-5.

${ }^{\mathrm{C} B y e r s ~(1983), ~ F i g . ~ 3 ; ~ I e, ~ I d, ~ a n d ~(S)-c i s-v e r b e n o l ~(n g / m i n) ; ~ e q . ~ E: ~ a ~=~ 93.8, ~ b ~=~ 5.71 E-9, ~ c ~=~ 5.283 . ~}$

${ }^{\mathrm{d}}$ Byers and Wood (1981), Coleoptera: Curculionidae, Fig. 3 (ng/min) frontalin, exo-brevicomin and myrcene, female eq. G: a $=36.94$, b = 32.67, c = 43.59, d = 0.0102 ; male eq. $\mathrm{D}$ : $\mathrm{a}=21.03, \mathrm{~b}=49.02, \mathrm{c}=1.01, \mathrm{~d}=0.0239$. 
${ }^{\mathrm{e}}$ Byers et al. (1990), Coleoptera: Curculionidae, Fig. 3 (ng/min), varied (E,Z)-2,4-methyl decadienoate (MD) with 22 ng/min chalcogran $(\mathrm{CH})$, eq. L: a = 28.55, b = 28.96, c $=24.58, \mathrm{~d}=16.17$, e = 0.08; or varied $\mathrm{CH}$ with $22 \mathrm{ng} / \mathrm{min} \mathrm{MD}$, eq. $\mathrm{N}$ : a $=18.24, \mathrm{~b}=56.4, \mathrm{c}=0.0094$.

${ }^{\mathrm{f}}$ Byers (2012c), Coleoptera: Curculionidae, Table 3 (ng/min), grandisol and (S)-cis-verbenol, eq. $\mathrm{N}$ : a $=-79.63$, b $=125.097, \mathrm{c}=0.0278$.

${ }^{\mathrm{g}}$ Teale and Lanier (1991), Coleoptera: Curculionidae, Fig. 5 (male frass), eq. $\mathrm{N}$ : a $=25.59, \mathrm{~b}=38.03$, c $=0.0014$.

${ }^{\mathrm{h}}$ Teale et al. (1991), Fig. 1 (aeration extract), eq. R: $\mathrm{a}=20.57, \mathrm{~b}=59.08, \mathrm{c}=6.3 \mathrm{E}-5$.

${ }^{\mathrm{i} B e l l a s}$ and Bartell (1983), Lepidoptera: Tortricidae, Table 1 (ng), 14:1 ratio $(E)-11-14:$ OAc to $(E, E)-9,11-14: 0 A c ;$ eq. B: a = 18.15, b = 63.54, c = 0.999.

${ }^{j}$ Antony et al. (1985), ; Diptera: Drosophilidae, Fig. 3A (ng) male vibrations for 7,11-27:Hy natural eq. A: a = 23.79, b = 0.014; 7,11-27:Hy eq. B: a = -3432, b = $3449, \mathrm{c}=0.0389 ; 7-25:$ Hy natural eq. $\mathrm{J}: \mathrm{a}=-38.75, \mathrm{~b}=58.16, \mathrm{c}=0.011, \mathrm{~d}=0.011 ; 7-25: \mathrm{Hy} \mathrm{eq} . \mathrm{F}: \mathrm{a}=-2.207 \mathrm{E}+7, \mathrm{~b}=2.207 \mathrm{E}+7, \mathrm{c}=0.00158, \mathrm{~d}=1.628$.

${ }^{\mathrm{k}}$ Gemeno et al. (2003), Dictyoptera: Blattellidae, Fig. 1 (pg), males attracted to sex pheromone 2R,4R eq. L: a = -795, b = 833.9, c $=3.45$, d = 56.3, e = 0.061; 2S,4R eq. $\mathrm{J}: \mathrm{a}=0.189, \mathrm{~b}=94.6, \mathrm{c}=0.073, \mathrm{~d}=0.107$

${ }^{\mathrm{l}}$ Preiss and Priesner (1988), Lepidoptera: Tortricidae, Fig. 1 (ng), eq. B: $\mathrm{a}=12.8, \mathrm{~b}=55.6, \mathrm{c}=6.395$.

${ }^{\mathrm{m}}$ Schal et al. (1990), Dictyoptera: Blattellidae, Fig. 1 (ng), male wing-raising to 3,11-dimethyl-2-nonacosanone, eq. $\mathrm{D}: \mathrm{a}=6$, b = 94.8, c = 0.205, d = 0.0025.

${ }^{\mathrm{n}}$ Valeur et al. (2000), Lepidoptera: Noctuidae, Fig. 4 (ng), male orientation in wind tunnel to blend of Z5-10:OAc/Z7-12:OAc/Z9-14:OAc/Z5-12:OAc at 1:5:2.5:0.25 ratios, eq. $\mathrm{K}: \mathrm{a}=2.22$, $\mathrm{b}=0.46, \mathrm{c}=12.63$, $\mathrm{d}=0.0064$.

${ }^{\circ}$ Peschke and Metzler (1987), Coleoptera: Staphylinidae, Fig. $4(\mu \mathrm{g})$, male genital grasping of sex pheromone: Z7-21:Hy, eq. I: a = 54.6, b = 44.5, c = 44.6.

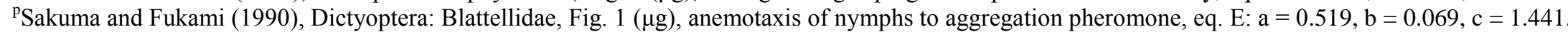

Table S3. Logarithmic $[\mathrm{Y}=\mathrm{a}+\mathrm{b} \ln (\mathrm{X})]$ and non-linear (kinetic formation A-R) regressions describing the relationship between dosage of ethanol or pheromone $(\mathrm{X})$ and trap captures for various insects $(\mathrm{Y})$ in the field.

\begin{tabular}{|c|c|c|c|c|}
\hline Insect species - attractant & Dosages (X) & Catches (Y) & $\begin{array}{l}\text { Logarithmic } \\
\text { adjusted } \mathrm{R}^{2}\end{array}$ & Kinetic formation A-R (adjusted $\left.\mathrm{R}^{2}\right)^{\mathrm{a}}$ \\
\hline Pityogenes chalcographus - pheromone ${ }^{b}$ & $0.1,1,10$ & 665, 1968, 2772 & 0.963 & A (0.908); Q (0.999); O (0.987); M (0.987) \\
\hline Dendroctonus brevicomis - pheromone ${ }^{\mathrm{c}}$ & $0.43,4.3,43$ & 189, 1402, 1773 & 0.828 & $\mathrm{~A}(0.994) ; \mathrm{O}(0.950) ; \mathrm{M}(0.950) ; \mathrm{Q}(0.909)$ \\
\hline D. brevicomis - frontalin ${ }^{\mathrm{d}}$ & $0.015,0.15,1.5$ & $110,205,325$ & 0.991 & $\mathrm{~A}(0.500) ; \mathrm{Q}(0.877)$ \\
\hline D. brevicomis - exo-brevicomin ${ }^{\mathrm{e}}$ & $0.015,0.15,1.5$ & $128,282,325$ & 0.809 & A (0.919); O (0.999); M (0.999); Q (0.982) \\
\hline I. typographus $-\mathrm{MB}^{\mathrm{f}}$ & $0.5,5,50,500,5000$ & $16,27,163,225,308$ & 0.916 & K (0.989); G (0.989); F (0.931); R (0.916) \\
\hline I. typographus $-\mathrm{cV}^{\mathrm{f}}$ & $0.01,0.1,1,10$ & $147,596,1501,1988$ & 0.945 & E (0.996); C (0.971); B (0.954); R (0.999) \\
\hline Ips typrographus - pheromone $12 \mathrm{~m}^{\mathrm{g}}$ & $1.2,5.796,57$ & $10,80,753$ & 0.787 & A (0.999); O (0.999); M (0.999); Q (0.999) \\
\hline I. typrographus - pheromone, $1.5-12 \mathrm{~m}^{\mathrm{g}}$ & $1.2,5.796,57$ & 373, 1390, 2082 & 0.909 & A (0.997); M (0.968); O (0.968); Q (0.944) \\
\hline Hylurgops palliatus - ethanol ${ }^{\mathrm{h}}$ & $8,80,800$ & $75,196,411$ & 0.949 & $\mathrm{~A}(0.919) ; \mathrm{Q}(0.952)$ \\
\hline Trypodendron domesticum - ethanol ${ }^{\mathrm{h}}$ & $8,80,800$ & $16,52,105$ & 0.976 & A (0.960); Q (0.983); O (0.975); M (0.975) \\
\hline Tomicus piniperda - ethanol $^{\mathrm{h}}$ & $8,80,800$ & $2,28,24$ & 0.235 & A (0.814); M (0.609); O (0.609); Q (0.486) \\
\hline Rhizophagus ferrugineus - ethanol $^{\mathrm{h}}$ & $8,80,800$ & $12,89,290$ & 0.876 & A (0.999); Q (0.999); O (0.999); M (0.999) \\
\hline Planococcus citri - pheromone, July ${ }^{i}$ & $25,50,100,200,400,800$ & $117,122,196,215,278,178$ & 0.149 & A (0.429); B (0.221); C (0.174); P (0.065) \\
\hline P. citri - pheromone, May ${ }^{\mathrm{i}}$ & $25,50,100,200,400,800$ & $61,84,101,94,84,124$ & 0.362 & $\mathrm{~A}(0.337) ; \mathrm{Q}(0.370)$ \\
\hline
\end{tabular}




\begin{tabular}{|c|c|c|c|c|}
\hline Synanthedon vespiformis - pheromone, June ${ }^{j}$ & $0.2,0.5,1,2,4$ & $38,84,120,104,282$ & 0.472 & J (0.662); K (0.590); G (0.578); P (0.579) \\
\hline S. vespiformis - pheromone, August $\mathrm{j}^{j}$ & $1,2,4,8,16$ & $70,68,165,133,284$ & 0.547 & K (0.474); G (0.466); B (0.456); P (0.456) \\
\hline Etiella zinckenella - pheromone, Hungary ${ }^{\mathrm{k}}$ & $1,10,100,1000$ & $8,33,61,73$ & 0.929 & E (0.999); C (0.976); R (0.999); Q (0.999) \\
\hline E. zinckenella - pheromone, Egypt ${ }^{\mathrm{k}}$ & $1,10,100,1000$ & $2,11,28,30$ & 0.788 & C (0.999); E (0.998); B (0.993); N (0.986) \\
\hline Ips pini - lanierone ${ }^{1}$ & $0.0001,0.001,0.01,0.1,1$ & $15,38,76,152,77$ & 0.045 & $\mathrm{~A}(0.332) ; \mathrm{M}(0.380) ; \mathrm{O}(0.380) ; \mathrm{Q}(0.345)$ \\
\hline Anomala octiescostata - pheromone $^{\mathrm{m}}$ & $0.1,1,10,100$ & $90,280,333,491$ & 0.884 & E (0.815); C (0.629); B (0.544); R (0.771) \\
\hline 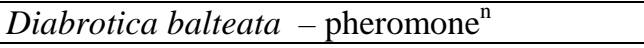 & 30, 99.9, 300, 1000 & $5.1,13.4,24.8,14.5$ & 0.000 & I (0.132); B (0.129); E (0.124); N (0.000) \\
\hline Neodiprion sertifer - diprionyl acetate ${ }^{0}$ & See footnotes & $21.7,44.6,46.3,80,70.3,103.4$ & 0.841 & E (0.700); R (0.728) \\
\hline N. sertifer - diprionyl acetate - Fig. $6^{0}$ & $0.11,1.1,1.9,18.3,120.2$ & $6,14.8,33.4,40.2,39.5$ & 0.594 & A (0.858); F (0.732); B (0.730); N (0.614) \\
\hline
\end{tabular}

${ }^{a}$ Up to three kinetic formation regressions A-L (Table 1) listed from left to right in order of best fit using adjusted $\mathrm{R}^{2}>$ logarithmic $\mathrm{R}^{2}$, and one or more best-fitting formulas $\mathrm{M}-\mathrm{R}$, (if $\mathrm{R}^{2}$ of formation functions < logarithmic $\mathrm{R}^{2}$ then only the top two formulas of each category are shown).

${ }^{\mathrm{b}}$ Byers et al. (1988), Coleoptera: Curculionidae, Table 1, test 4, (x $18 \mu \mathrm{g} /$ day methyl decadienoate or x 1 mg/day chalcogran) aggregation pheromone components; eq. $\mathrm{Q}: \mathrm{a}=3179, \mathrm{~b}=2.94 \mathrm{E}-7$.

${ }^{\mathrm{c}}$ Tilden and Bedard (1985), Coleoptera: Curculionidae, Table 4 (mg/day each) of frontalin, exo-brevicomin, and myrcene, eq. A: a = 1782 , b = 0.3463.

${ }^{\mathrm{d} B y e r s ~(1988), ~ T a b l e ~} 1$ (mg/day); varied frontalin plus $1.5 \mathrm{mg}$ /day each of exo-brevicomin and myrcene, eq. log.: a = 301.9, b = 46.687.

${ }^{\mathrm{e}}$ Byers (1988), Table 1 (mg/day); varied exo-brevicomin plus $1.5 \mathrm{mg} /$ day each of frontalin and myrcene, eq. O: a = 328.85, b = 0.0238.

${ }^{\mathrm{f}}$ Schlyter et al. (1987a), Coleoptera: Curculionidae, Table 2 (mg/day); varied 2-methyl-3-buten-2-ol (MB) plus 1 mg/day cis-verbenol (cV), eq. K: a = 206.38, b = $0.03, \mathrm{c}=127.8, \mathrm{~d}=0.00032$; or varied cV with $50 \mathrm{mg} /$ day $\mathrm{MB}$, eq. $\mathrm{E}$ : $\mathrm{a}=2257, \mathrm{~b}=2.445 \mathrm{E}-7$, c $=3.1662$ (used in Figure 6).

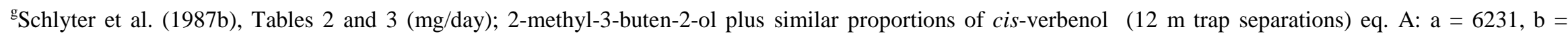
0.00226 ; (combined 1.5 to $12 \mathrm{~m}$ trap separations) eq. A: $\mathrm{a}=2087, \mathrm{~b}=0.1844$.

${ }^{\mathrm{h}}$ Byers (1992), Coleoptera: Curculionidae, Table 2 (mg/day); H. palliates eq. Q: a = 530.2, b = 3.89E-8, T. domesticum eq. Q: a = 135.6, b = 6.06E-7, and T. piniperda eq. $\mathrm{A}: \mathrm{a}=25.6, \mathrm{~b}=0.0358$, and (Coleoptera: Monotomidae) $R$. ferrugineus eq. $\mathrm{A}: \mathrm{a}=298.6, \mathrm{~b}=0.0044$.

íZada et al. (2004), Hemiptera: Pseudococcidae, Fig. 5 ( $\mu$ g), July eq. A: a = 223.9, b = 0.021; May eq. L: a = -95.3, b = 181.97, c = 0.0769, d = 36060, e = 1.035E-6.

${ }^{\mathrm{j}}$ Levi-Zada et al. (2011), Lepidoptera: Sesiidae, Table 3 (mg); June eq. $\mathrm{J}: \mathrm{a}=68.6, \mathrm{~b}=22704, \mathrm{c}=0.0357$, $\mathrm{d}=0.0357$; August eq. log.: a $=45.4$, b $=71.12$.

${ }^{\mathrm{k}}$ Tóth et al. (1989), Lepidoptera: Phycitidae, Table $3(\mu \mathrm{g})$; Hungary eq. $\mathrm{E}: \mathrm{a}=80.69, \mathrm{~b}=3.82 \mathrm{E}-6, \mathrm{c}=3.331 ; \mathrm{Egypt}$ eq. C: a = 30.01, b =0.0164, c = 0.0013.

'Teale et al. (1991), Fig. 11 (mg), eq. A: a = 112.8, b = 138.8; varied lanierone plus constant ipsdienol.

${ }^{\mathrm{m}}$ Leal et al. (1994), Coleoptera: Scarabaeidae, Fig. 3 (mg); eq. log.: a = 235.7, b = 54.55. 
${ }^{\mathrm{n}}$ Chuman et al. (1987), Coleoptera: Chrysomelidae, Table 3 ( $\mu$ g); eq. I: a = 19.4, b=0.0165, c $=0.0657$.

${ }^{\circ}$ Anderbrant et al. (1992), Hymenoptera: Diprionidae, $X=0.09,0.45,1.44,22.5,96.75,281.25$; Fig. 5 ( $\mu$ g/day), eq. log.: a = 45.8, b = 8.74; Fig. 6 ( $\mu$ g/day), eq. A: a $=40.26, \mathrm{~b}=0.648$.

\section{References}

AL ABASSI, S., BIRKETT, M. A., PETTERSSON, J., PICKETT, J. A., WADHAMS, L. J., and WOODCOCK, C. M. 2000. Response of the seven-spot ladybird to an aphid alarm pheromone and an alarm pheromone inhibitor is mediated by paired olfactory cells. J. Chem. Ecol. 26:1765-1771.

ANDERBRANT, O., BENGTSSON, M., LÖFQVIST, and BAECKSTRÖM, P. 1992. Field response of the pine sawfly Neodiprion sertifer to controlled release of diprionyl acetate, diprionyl proprionate and trans-perillenal. J. Chem. Ecol. 18:1707-1725.

ANDERSON, P., HILKER, M., HANSSON, B. S., BOMBOSH, S., KLEIN, B., SCHILDKNECHT, H. 1993. Oviposition deterring components in larval frass of Spodoptera littoralis (Boisd.) (Lepidoptera: noctuidae): a behavioural and electrophysiological evaluation. J. Insect Physiol. 39:129-137.

ANTONY, C., DAVIS, T. L., CARLSON, D. A., PECHINE, J. M., and JALLON, J. M. 1985. Compared behavioral responses of male Drosophila melanogaster (Canton S) to natural and synthetic aphrodisiacs. J. Chem. Ecol. 11:1617-1629.

BELLAS, T. E., and BARTELL, R. J. 1983. Dose-response relationship for two components of the sex pheromone of lightbrown apple moth, Epiphyas postvittana (Lepidoptera: Tortricidae). J. Chem. Ecol. 9:715-725.

BYERS, J. A. 1983. Sex-specific responses to aggregation pheromone: Regulation of colonization density in the bark beetle Ips paraconfusus. J. Chem. Ecol. 9:129-142.

BYERS, J. A. 1988. Novel diffusion-dilution method for release of semiochemicals: Testing pheromone component ratios on western pine beetle. J. Chem. Ecol. 14:199-212.

BYERS, J. A. 1992. Attraction of bark beetles, Tomicus piniperda, Hylurgops palliatus, and Trypodendron domesticum and other insects to short-chain alcohols and monoterpenes. J. Chem. Ecol. 18:2385-2402. 
BYERS, J. A. 2012c. Bark beetles, Pityogenes bidentatus, orienting to aggregation pheromone avoid conifer monoterpene odors when flying but not when walking. Psyche J. Entomol. vol. 2012, ID 940962, pp. 1-10.

BYERS, J. A., and WOOD, D. L. 1981. Interspecific effects of pheromones on the attraction of the bark beetles, Dendroctonus brevicomis and Ips paraconfusus in the laboratory. J. Chem. Ecol. 7:9-18.

BYERS, J. A., BIRGERSSON, G., LÖFQVIST, J., and BERGSTRÖM, G. 1988. Synergistic pheromones and monoterpenes enable aggregation and host recognition by a bark beetle, Pityogenes chalcographus. Naturwissenschaften 75:153-155.

BYERS, J. A., BIRGERSSON, G., LÖFQVIST, J., APPELGREN, M., and BERGSTRÖM, G. 1990. Isolation of pheromone synergists of bark beetle, Pityogenes chalcographus, from complex insect-plant odors by fractionation and subtractivecombination bioassay. J. Chem. Ecol. 16:861-876.

BYERS, J. A., WOOD, D. L., BROWNE, L. E., FISH, R. H., PIATEK, B., and HENDRY, L. B. 1979. Relationship between a host plant compound, myrcene and pheromone production in the bark beetle, Ips paraconfusus. J. Insect Physiol. 25:477-482.

CHUMAN, T., GUSS, P. L., DOOLITTLE, R. E., MCLAUGHLIN, J. R., KRYSAN, J. L., SCHALK, J. M., and TUMLINSON, J. H. 1987. Identification of female-produced sex pheromone from banded cucumber beetle, Diabrotica balteata LeConte (Coleoptera: Chrysomelidae). J. Chem. Ecol. 13:1601-1616.

COSSÉ, A. A., and BARTELT, R. J. 2000. Male-produced aggregation pheromone of Colopterus truncates: Structure, electrophysiological, and behavioral activity. J. Chem. Ecol. 26:1735-1748.

DELORME, J. D., and PAYNE, T. L. 1990. Antennal olfactory responses of black turpentine beetle, Dendroctonus terebrans (Olivier), to bark beetle pheromones and host terpenes. J. Chem. Ecol. 16:1321-1329.

DICKENS, J. C. 1989. Green leaf volatiles enhance aggregation pheromone of boll weevil, Anthonomus grandis. Entomol. Exp. Appl. 52:191-203.

DICKENS, J. C., OLIVER, J. E., and MASTRO, V. C. 1997. Response and adaptation to analogs of disparlure by specialist antennal receptor neurons of gypsy moth, Lymantria dispar. J. Chem. Ecol. 23:2197-2210.

DOLZER, J., FISCHER, K., and STENGL, M. 2003. Adaptation in pheromone-sensitivie trichoid sensilla of the hawkmoth Manduca 
sexta. J. Exper. Biol. 206:1575-1588.

GEMENO, C., LEAL, W. S., MORI, K., and SCHAL, C. 2003. Behavioral and electrophysiological responses of the brownbanded cockroach, Supella longipalpa, to stereoisomers of its sex pheromone, supellapyrone. J. Chem. Ecol. 29:1797-1811.

GRANT, A. J., and LANIER, G. N. 1982. Electroantennogram responses of Scolytus multistriatus (Coleoptera: Scolytidae) to its pheromone components and to associated compounds. J. Chem. Ecol. 8:1333-1344.

HILBUR, Y., BENGTSSON, M., LÖFQVIST, J., BIDDLE, A., PILLON, O., PLASS, E., FRANCKE, W., and HALLBERG, E. 2001. A chiral sex pheromone system in the pea midge, Contarinia pisi. J. Chem. Ecol. 27:1391-1407.

JEWETT, D. K., BRIGHAM, D. L., and BJOSTAD, L. B. 1996. Hesperophylax occidentalis (Trichoptera: Limnephilidae): Electroantennogram structure-activity study of sex pheromone component 6-methylnonan-3-one. J. Chem. Ecol. 22:123-137.

LANNE, B. S., SCHLYTER, F., BYERS, J. A., LÖFQVIST, J., LEUFVÉN, A., BERGSTRÖM, G., Van Der PERS, J. N. C., UNELIUS, R., BAECKSTRÖM, P., and NORIN, T. 1987. Differences in attraction to semiochemicals present in sympatric pine shoot beetles, Tomicus minor and T. piniperda. J. Chem. Ecol. 13:1045-1067.

LEAL, W. S., HASEGAWA, M., SAWADA, M., ONO, M., and UEDA, Y. 1994. Identification and field evaluation of Anomala octiescostata (Coleoptera: Scarabaeidae) sex pheromone. J. Chem. Ecol. 20:1643-1655.

LEVI-ZADA, A., BEN-YEHUDA, S., DUNKELBLUM, E., GINDIN, G., FEFER, D., PROTASOV, A., KUZNETSOWA, T., MANULIS-SASSON, S., MENDEL, Z. 2011. Identification and field bioassays of the sex pheromone of the yellow-legged clearwing Synanthedon vespiformis (Lepidoptera: Sesiidae). Chemoecology 21:227-233.

LI, Y., DICKENS, J.C., and STEINER, W.W.M. 1992. Antennal olfactory responsiveness of Microplitis croceipes (Hymenoptera: Braconidae) to cotton plant volatiles. J. Chem. Ecol. 18:1761-1773.

LUCAS, P., and RENOU, M. 1989. Responses to pheromone compounds in Mamestra suasa (Lepidoptera: Noctuidae) olfactory neurons. J. Insect Physiol. 35:837-845.

MOORE, I. 1981. Biological amplification for increasing electroantennogram discrimination between two female sex pheromones of Spodoptera littoralis (Lepidoptera: Noctuidae). J. Chem. Ecol. 7:791-798. 
PESCHKE, K., and METZLER, M. 1987. Cuticular hydrocarbons and female sex pheromones of the rove beetle, Aleochara curtula (Goeze) (Coleoptera: Staphylinidae). Insect Biochem. 17:167-178.

PREISS, R., and PRIESNER, E. 1988. Responses of male codling moths (Laspeyresia pomonella) to codlemone and other alcohols in a wind tunnel. J. Chem. Ecol. 14:797-813.

SAKUMA, M., and FUKAMI, H. 1990. Dose/response relations in taxes of nymphs of the German cockroach, Blattella germanica (L.) (Dictyoptera: Blattellidae) to their aggregation pheromone. Appl. Entomol. Zool. 25:9-16.

SCHAL, C., BURNS, E. L., JURENKA, A., and BLOMQUIST, G. J. 1990. A new component of the female sex pheromone of Blattella germanica (L.) (Dictyoptera: Blattellidae) and interaction with other pheromone components. J. Chem. Ecol. 16:1997-2008.

SCHLYTER, F., LÖFQVIST, J., and BYERS, J. A. 1987a. Behavioural sequence in attraction of the bark beetle Ips typographus to pheromone sources. Physiol. Entomol. 12:185-196.

SCHLYTER, F., BYERS, J. A., and LÖFQVIST, J. 1987b. Attraction to pheromone sources of different quantity, quality, and spacing: Density-regulation mechanisms in bark beetle Ips typographus. J. Chem. Ecol. 13:1503-1523.

TEALE, S. A., and LANIER, G. N. 1991. Seasonal variability in response of Ips pini (Coleoptera: Scolytidae) to ipsdienol in New York. J. Chem. Ecol. 17:1145-1158.

TEALE, S. A., WEBSTER, F. X., ZHANG, A., and LANIER, G. N. 1991. Lanierone: A new pheromone component from Ips pini (Coloeptera: Scolytidae) in New York. J. Chem. Ecol. 17:1159-1176.

TILDEN, P. E., and BEDARD, W. D. 1985. Field response of Dendroctonus brevicomis to exo-brevicomin, frontalin, and myrcene released at two proportions and three levels. J. Chem. Ecol. 11:757-766.

TODD, J. L., MILLAR, J. G., VETTER, R. S., and BAKER, T. C. 1992. Behavioral and electrophysiological activity of (Z,E)-7,9,11dodecatrienyl formate, a mimic of the major sex pheromone component of carob moth, Ectomyelois ceratoniae. J. Chem. Ecol. 18:2331-2352. 
TÓTH, M., LÖFSTEDT, C., HANSSON, B. S., SZÖCS, G., and FARAG, A. I. 1989. Identification of four components from the female sex pheromone of the lima-bean pod borer, Etiella zinckenella. Entomol. Exp. Appl. 51:107-112.

TØMMERÅS, B. Å, MUSTAPARTA, H., and GREGOIRE, J.-CL. 1984. Receptor cells in Ips typographus and Dendroctonus micans specific to pheromones of reciprocal genus. J. Chem. Ecol. 10:759-769.

VALEUR, P., HANSSON, B. S., MARKEBO, K., and LÖFSTEDT, C. 2000. Relationship between sex pheromone elicited behaviour and response of single olfactory receptor neurons in a wind tunnel. Physiol. Entomol. 25:223-232.

WHITEHEAD, A. T. 1986. Electroantennogram responses by mountain pine beetles, Dendroctonus ponderosae Hopkins, exposed to selected semiochemicals. J. Chem. Ecol. 7:1603-1621.

WU, W. Q., COTTRELL, C. B., HANSSON, B. S., and LÖFSTEDT, C. 1999. Comparative study of pheromone production and response in Swedish and Zimbabwean populations of turnip moth, Agrotis segetum. J. Chem. Ecol. 25:177-196.

ZADA, A., DUNKELBluM, E., HAREL, M., ASSAEL, F., GROSS, S., and MENDEL, Z. 2004. Sex pheromone of the citrus mealybug Planococcus citri: Synthesis and optimization of trap parameters. J. Econ. Entomol. 97:361-368.

ZHU, J., COSSÉ, A. A., OBRYCKI, J. J., BOOK, K. S., and BAKER, T. C. 1999. Olfactory reactions of the twelve-spotted lady beetle, Coleomegilla maculata and the green lacewing, Chrysoperla carnea to semiochemicals released from their prey and host plant: electroantennogram and behavioral responses. J. Chem. Ecol. 25:1163-1177. 